\title{
Forest birds respond to the spatial pattern of exurban development in the Mid-Atlantic region, USA
}

Marcela Suarez-Rubio, Todd R Lookingbill

Housing development beyond the urban fringe (i.e. exurban development) is one of the fastest growing forms of land-use change in the United States. Exurban development's attraction to natural and recreational amenities has raised concerns for conservation and represents a potential threat to wildlife. Although forest-dependent species have been found particularly sensitive to low housing densities, it is unclear how the spatial distribution of houses affects forest birds. The aim of this study was to assess forest bird responses to changes in the spatial pattern of exurban development and also to examine species responses when forest loss and forest fragmentation were considered. We evaluated landscape composition around North American Breeding Bird Survey stops between 1986 and 2009 by developing a compactness index to assess changes in the spatial pattern of exurban development over time. Compactness was defined as a measure of how clustered exurban development was in the area surrounding each survey stop at each time period considered. We used Threshold Indicator Taxa Analysis to detect the response of forest and forest-edge species in terms of occurrence and relative abundance along the compactness gradient at two spatial scales (400-m and 1-km radius buffer). Our results show that most forest birds and some forest-edge species were positively associated with high levels of compactness at the larger spatial scale although the proportion of forest in the surrounding landscape had also a significant effect when forest loss and forest fragmentation were accounted for. In contrast, the spatial configuration of exurban development was an important predictor of occurrence and abundance for only a few species at the smaller spatial scale. The positive response of forest birds to compactness at the larger scale could represent a systematic trajectory of decline and could be highly detrimental to bird diversity if exurban growth continues and creates more compacted development. 
1 Forest birds respond to the spatial pattern of exurban development in the Mid-Atlantic

2 region, USA

3

4 Marcela Suarez-Rubio ${ }^{1}$, Todd R. Lookingbill ${ }^{2}$

5

$6{ }^{1}$ Institute of Zoology, University of Natural Resources and Life Sciences, Vienna, Austria

7

$8{ }^{2}$ Department of Geography and the Environment, University of Richmond, Richmond, VA, 9 USA

10

11 Corresponding author:

12 Marcela Suarez-Rubio ${ }^{1}$

13 Gregor Mendel-Strasse 33, A-1180 Vienna, Austria

14 E-mail: marcela.suarezrubio@boku.ac.at 


\section{ABSTRACT}

16 Housing development beyond the urban fringe (i.e. exurban development) is one of the fastest

17 growing forms of land-use change in the United States. Exurban development's attraction to

18 natural and recreational amenities has raised concerns for conservation and represents a potential

19 threat to wildlife. Although forest-dependent species have been found particularly sensitive to

20 low housing densities, it is unclear how the spatial distribution of houses affects forest birds. The

21 aim of this study was to assess forest bird responses to changes in the spatial pattern of exurban

22 development and also to examine species responses when forest loss and forest fragmentation

23 were considered. We evaluated landscape composition around North American Breeding Bird

24 Survey stops between 1986 and 2009 by developing a compactness index to assess changes in

25 the spatial pattern of exurban development over time. Compactness was defined as a measure of

26 how clustered exurban development was in the area surrounding each survey stop at each time

27 period considered. We used Threshold Indicator Taxa Analysis to detect the response of forest

28 and forest-edge species in terms of occurrence and relative abundance along the compactness

29 gradient at two spatial scales (400-m and 1-km radius buffer). Our results show that most forest

30 birds and some forest-edge species were positively associated with high levels of compactness at

31 the larger spatial scale although the proportion of forest in the surrounding landscape had also a

32 significant effect when forest loss and forest fragmentation were accounted for. In contrast, the

33 spatial configuration of exurban development was an important predictor of occurrence and

34 abundance for only a few species at the smaller spatial scale. The positive response of forest

35 birds to compactness at the larger scale could represent a systematic trajectory of decline and

36 could be highly detrimental to bird diversity if exurban growth continues and creates more

37 compacted development. 
As the world's human population has grown over the last century and residential housing has continued to sprawl even in areas where human population is declining (Pendall 2003; Seto et al.

41 2012), the rapid increase of housing development has expanded not only at the edge of cities but

42 also beyond the urban fringe to increasingly more rural areas (e.g., Davis \& Hansen 2011; Hansen et al. 2005; Marzluff 2001; McKenzie et al. 2011; Suarez-Rubio et al. 2012a). Housing development beyond the urban fringe (i.e. exurban development) is characterized by low-density, scattered housing units farther away than the suburbs but within commuting distance to an urban center (Berube et al. 2006; Daniels 1999; Lamb 1983; Nelson 1992; Theobald 2001). In the conterminous USA, low-density development has been prominent since the 1950s (Brown et al. 2005 ) and growing at a rate of about $10 \%$ to $15 \%$ per year (Theobald 2001). By $2000,25 \%$ of the nation was already considered exurbia (Brown et al. 2005) and forecasts have indicated that this pattern of land use will continue into the future (Brown et al. 2014; Kirk et al. 2012). amenities (Gonzalez-Abraham et al. 2007; Hammer et al. 2004) has raised environmental and ecological concerns (Gude et al. 2006; Hansen et al. 2005; Leu et al. 2008; Sampson \& DeCoster 2000). Exurban development can alter disturbance regimes such as wildfires (NIFC 2013; Radeloff et al. 2005) and biogeochemical cycles by changing greenhouse gas fluxes (Dale et al. 2005; Huang et al. 2014). By converting natural habitats into exurban development habitat is lost and fragmented which reduces habitat quality for many native species and increases habitat quality for many early successional and non-native species (Donnelly \& Marzluff 2006). In addition to the loss of vegetation cover, changes in structural complexity around houses in 
61 Knight 2001) by degrading habitats and natural resources (Friesen et al. 1995; Suarez-Rubio et

62 al. 2013; Theobald et al. 1997). As a consequence, exurban development has been linked to

63 reduced survival and reproduction of some wildlife species (Riley et al. 2003; Tewksbury et al.

64 1998) and changes in the behavior and habitat use of other species, for example by interrupting

65 bird migration and movement (Lepczyk et al. 2004; Miller et al. 1998).

66 Forest birds have been found particularly sensitive to new housing (Pidgeon et al. 2007)

67 even at densities as low as 0.095 houses/ha (Friesen et al. 1995; Merenlender et al. 2009; Suarez-

68 Rubio et al. 2011). Area-sensitive, some cavity-nesting, and bark-foraging birds are relatively

69 more susceptible to the effects of exurban development than granivores, omnivores, and ground

70 foragers (Fraterrigo \& Wiens 2005; Glennon \& Kretser 2013; Kluza et al. 2000; Merenlender et

71 al. 2009). Although the mechanisms are not well understood, changes in bird communities have

72 been associated with increased predation (Engels \& Sexton 1994; Lumpkin et al. 2012), brood

73 parasitism (Chace et al. 2003), free-roaming pets (Dauphiné \& Cooper 2009), and activities of

74 landowners (Lepczyk et al. 2004).

75 The effects of exurban development extend beyond immediate house surroundings. In the

76 Rocky Mountain region of the western USA, an impact zone of up to $180 \mathrm{~m}$ from houses has

77 been observed for bird and small-mammal communities (Odell \& Knight 2001). Similarly, in the

78 northeastern USA, an ecological effect zone of up to $200 \mathrm{~m}$ has been documented for breeding

79 birds (Glennon \& Kretser 2013). It is likely that the size of the zone of influence of exurban

80 development is dependent upon the spatial distribution of houses (Hansen et al. 2005). If houses

81 are clustered, the ecological effects of each house overlap, reducing the overall negative impacts.

82 Thus, clustered development is thought to minimize impacts on wildlife habitat relative to highly

83 dispersed low-density housing (Gagné \& Fahrig 2010; Glennon \& Kretser 2013; Odell et al. 
84 2003; Theobald et al. 1997). Although the relative importance of habitat quantity over habitat

85 pattern has been shown especially for birds in fragmented systems (Alberti \& Marzluff 2004;

86 Donnelly \& Marzluff 2006; Fahrig 1997; Lichstein et al. 2002), little is known about how the

87 spatial pattern of exurban areas changes as this form of development progresses and whether

88 forest birds respond to changes in exurban spatial pattern.

89 The aim of this study was to assess forest bird responses to changes in the spatial pattern of

90 exurban development and also to examine species responses when forest loss and forest

91 fragmentation were considered. We developed a compactness index to quantify the spatial

92 configuration of exurban development around North American Breeding Bird Survey stops in the

93 Mid-Atlantic region of the USA between 1986 and 2009 and assessed the response of selected

94 bird species (i.e., forest and forest-edge species) along this compactness gradient. In addition, we

95 determined whether species responded differently to exurban patterns at the local (400-m radius

96 buffer) and landscape scale (1-km radius buffer). We hypothesized that exurban development

97 would become more compact overtime and thus forest birds would exhibit a decrease in

98 occurrence and relative abundance, whereas forest-edge species would respond positively to

99 compactness of exurban development. To our knowledge, this is the first time that a continuous

100 gradient approach has been used to quantify compactness as exurban development progresses

101 and to identify threshold responses along this gradient.

\section{MATERIALS AND METHODS}

\section{Study area}

104 Our study area encompassed approximately $4300 \mathrm{~km}^{2}$ and included nine counties in north-central

105 Virginia (Clarke, Culpeper, Fauquier, Frederick, Madison, Page, Rappahannock, Shenandoah, 106 and Warren) and two in western Maryland (Washington and most of Frederick; Fig. 1), USA. 
107 The region has experienced high population growth rates, ranging from $4 \%$ (Page County) to

$10836 \%$ (Culpeper County) in the past decade (U.S. Census Bureau 2013). The region has also

109 experienced an increase in exurban settlements over the same time period (Suarez-Rubio et al.

110 2012a), stimulated at least in part by the close proximity of natural amenities (Suarez-Rubio et

111 al. 2012b).

\section{Breeding bird survey}

113 Using the North America Breeding Bird Survey (BBS) (Peterjohn \& Sauer 1994; Sauer et al.

114 2003), a large-scale annual roadside survey to monitor the status and trend of breeding bird

115 populations in the USA and southern Canada, we selected two groups of species that represent

116 contrasting habitat preferences (forest vs. edge). Forest species - Ovenbird (Seiurus

117 aurocapilla), Red-eyed Vireo (Vireo olivaceus), American Redstart (Setophaga ruticilla), Wood

118 Thrush (Hylocichla mustelina), Scarlet Tanager (Piranga olivacea), and Eastern Wood-Pewee

119 (Contopus virens) (Poole 2005) - were defined as birds that use a wide variety of deciduous and

120 mixed deciduous-coniferous forests and that might favor interior forested habitats (Mikusiñski et

121 al. 2001). Forest-edge species - Eastern Towhee (Pipilo erythrophthalmus), Eastern Phoebe

122 (Sayornis phoebe), Gray Catbird (Dumetella carolinensis), Northern Cardinal (Cardinalis

123 cardinalis), and Indigo Bunting (Passerina cyanea) (Poole 2005) - are those species that are

124 strongly associated with forest edges and open habitats (Mikusiñski et al. 2001). These 11

125 species were also selected because they were detected on at least 5\% of surveys during the 1986-

1262009 interval. In addition, many of the species are reported to have experienced population

127 declines or reduced fecundity due to habitat loss or fragmentation (Donovan \& Flather 2002;

128 Hagan 1993; Sherry \& Holmes 1997; U.S. NABCI Committee 2009). 
BBS routes involve $39.4 \mathrm{~km}$-long road transects, with 3-minute point count surveys

130 conducted at stops every $0.8 \mathrm{~km}$. From each BBS route located in the study area, we selected

131 every fifth stop along the route to reduce overlap between adjacent areas around survey stops and

132 decrease the likelihood of spatial autocorrelation (Moran's $\mathrm{I}=0.108, \mathrm{p}=0.182$ ). We only

133 considered survey stops that had detailed direction descriptions (i.e., geocoding information and

134 characterization of site-specific features) and fell within the study region (125 survey points in

135 total) (Fig. 1). We focused our analysis on survey stops instead of the entire route because of our

136 interest in local variability of breeding habitats.

137 To characterize local characteristics of breeding habitats, we established potential zones of

138 influence (Glennon \& Kretser 2013) of 400-m and 1-km radius around the selected BBS stops.

139 These areas represented both breeding bird territories (Bowman 2003; Mazerolle \& Hobson

140 2004), which were assumed to be in the immediate surroundings of survey stops, and areas

141 feasibly visited during bird daily movements (Krementz \& Powell 2000; Lang et al. 2002).

142 Within these areas, we quantified the proportion of forest and exurban development and the

143 spatial pattern of exurban development from 1986 to 2009.

144 We used a hierarchical Bayesian model to adjust BBS counts (Suarez-Rubio et al. 2013)

145 and account for BBS sources of variability such as observer differences (Sauer et al., 1994), first-

146 year observers' skills (Erskine 1978; Kendall et al. 1996), environmental conditions (Robbins et

147 al. 1986), and habitat features (Sauer et al. 1995). We modeled count data as hierarchical over-

148 dispersed Poisson and fit models using Markov Chain Monte Carlo (MCMC) methods in

149 WinBUGS 1.4.3 (Lunn et al. 2000). We specified $C_{i t}$ as the count for each species on stop $i$ and

150 time $t$ where $i=1, \ldots, \mathrm{N} ; t=1, \ldots, \mathrm{T}$; and $\mathrm{N}$ and $\mathrm{T}$ were the number of stops and the number of 
151 years species were observed, respectively. $C_{i t}$ was assumed to be Poisson distributed with mean

$152 \mu_{i t}$

$$
C_{i t} \sim \operatorname{Pois}\left(\mu_{i t}\right)
$$

154 and the full model was:

$$
\log \left(\mu_{i t}\right)=\beta_{\text {ostop }}+\beta_{\text {lstop }} \times \text { Year }_{t}+\beta_{2} \times \text { FirstYear }_{i t}+\text { Route }_{i t}+\text { Observer }_{i t}+\text { Error }_{i t}
$$

156 where each stop was assumed to have a separate intercept $\left(\beta_{0}\right)$ and time trend $\left(\beta_{1}\right)$. The model

157 included several sources of variability including unknown route environmental conditions and

158 habitat features $\left(\right.$ Route $\left._{i t}\right)$, observer effects $\left(\right.$ Observer $\left._{i t}\right)$, first-year observer effects (FirstYear $\left.{ }_{i t}\right)$

159 and over-dispersion effects $\left(\right.$ Error $\left._{i t}\right)$. Given that route conditions could also change among years,

160 we also included year into the model. We used two Markov chains for each model and examined

161 model convergence and performance through Gelman-Rubin diagnostics (Gelman et al. 2004;

162 Link \& Barker 2010). Once the model reached convergence, we derived estimates of the count at

163 each stop and in each year which were then used for the threshold analysis.

\section{Defining exurban development}

165 To characterize the land cover in the areas around survey stops, we classified Landsat 5 TM

166 images (pixel size: $30 \mathrm{~m}$ ) for 1986, 1993, 2000, and 2009. We performed standard pre-

167 processing procedures (atmospheric and topographic correction) prior to image classification and

168 conducted a supervised classification of areas of exurban development using a training dataset

169 generated from aerial photos. Exurban development was defined as areas with housing densities

170 between 1 unit per 0.4 ha and 1 unit per 16.3 ha (e.g., 6 - 250 houses per km²) (Brown et al.

171 2005). We identified exurban development using both spectral and structural characteristics

172 following the methods outlined in Suarez-Rubio (2012a). We derived spectral characteristics

173 from spectral mixture analysis (Adams et al. 1986) of the corrected Landsat images to estimate 
174 the fractional cover of vegetation, substrate, non-photosynthetic vegetation, and shade within

175 each image. Based on spectral mixture analysis outputs, we built decision trees to classify

176 exurban development for each of the four image dates.

177 To further analyze pixels belonging to branches of the decision trees that could not

178 discriminate between exurban and urban areas based on spectral characteristics alone, we used

179 morphological spatial pattern analysis (MSPA) (Soille 2003; Vogt et al. 2007). The analysis

180 evaluates map geometry by applying mathematical morphological operators to allocate each

181 pixel to one of a mutually exclusive set of classes. We used an 8-neighbor rule as our structural

182 element (i.e., both cardinal directions and diagonal neighbors are considered) and edge width of

183 one. Pixels that fell into the MSPA-Islet (representative of isolated housing units), Bridge,

184 Branch, and Loop classes (representative of associated roads) were considered exurban

185 development. All other MSPA classes were considered urban development. Lastly, all cells

186 originally designated as exurban development in the decision tree were then added back to attain

187 the final exurban development maps. Overall classification accuracy for the final exurban

188 development maps ranged from 93 to $98 \%$ (kappa: 0.87 to 0.96 ) (Suarez-Rubio et al. 2012a).

189 Analyzing the spatial pattern of exurban development

190 To examine the spatial pattern of exurban development, we used the final exurban development

191 maps as foreground and analyzed them using MSPA. Here, we focused specifically on the Islet

192 class which represented scattered, isolated housing units. Using the MSPA classification output,

193 we developed a compactness index to describe how clustered exurban development was in the

194 area surrounding each survey stop at each time period considered. The compactness index was a

195 measure of the proportion of exurban development within any MSPA classes other than the Islet

196 class (i.e., 1 - (Exurban Development islets / Exurban Development all classes)) and ranged 
197 from $0 \%$ (all Islets) to 100\% (no Islets). Survey stops lacking exurban development within the

198 potential zone of influence were excluded from the analysis ( 28 and 20 survey stops for the 400-

$199 \mathrm{~m}$ and 1-km radius buffers, respectively were excluded). Hence, dispersed exurban development

200 was represented by $0 \%$ and maximally clumped exurban development by $100 \%$ compactness

201 (see example in Fig. 2).

202 Identifying species response to compactness of exurban development

203 To examine the relationship between compactness of exurban development and bird species at

204 the survey stops, we fitted a non-parametric locally weighted polynomial regression (loess)

205 (Cleveland \& Devlin 1988). When the loess regression highlighted nonlinearity in the

206 relationship, then a change-point analysis was used to test for a nonlinear threshold response.

207 We estimated potential species threshold responses to compactness of exurban

208 development using Threshold Indicator Taxa ANalysis (TITAN) (Baker \& King 2010). TITAN

209 allows the identification of change points in both occurrence frequency and relative abundance

210 of individual species along an environmental gradient. It distinguishes responses of individual

211 species with low occurrence frequencies or highly variable abundances and does not assume a

212 linear response along all or part of an environmental gradient. TITAN uses normalized species

213 scores $(\mathrm{z})$ to establish a change-point location that separates the data into two groups and

214 maximizes association of each species with one side of the partition. $Z$ scores measure the

215 association of a species' abundance weighted by their occurrence and are normalized to facilitate

216 cross-species comparison. Thus, TITAN distinguishes if a species responds to an environmental

217 stressor (in this case compactness of exurban development) and whether the response is negative

218 (z-) or positive $\left(\mathrm{z}^{+}\right)$. 
To measure quality of the response and assess uncertainty around change-point locations,

220 TITAN bootstraps the original dataset and recalculates change points with each simulation.

221 Uncertainty is expressed as quantiles of the change-point distribution. Narrow intervals between

222 upper and lower change-point quantiles (i.e., 5 and 95\%) indicate a nonlinear response in species

223 abundance whereas broad quantile intervals are characteristic of species with a linear or more

224 gradual response. Diagnostic indices of the quality of the response are purity and reliability.

225 Purity is the proportion of bootstrap replicates that agree with the direction of the change-point

226 for the observed response. Pure indicators (purity $\geq 0.95$ ) are those that consistently assign the

227 same response direction during the resampling procedure. Reliability is the proportion of change-

228 point individual value scores (IndVal) among the bootstrap replicates that consistently have p-

229 values below defined probability levels (0.05). Reliable indicators (reliability $\geq 0.95)$ are those

230 with consistently large IndVal.

231 We ran TITAN (R package: TITAN2) (Baker \& King 2010) for the 11 selected bird

232 species and compactness index in R 3.1.1 (R Development Core Team 2013). We used the

233 minimum number of observations on each side of the threshold split that is required by TITAN

$234(\mathrm{n}=5)$ and specified 250 permutations to compute $\mathrm{z}$ scores and diagnostic indices as suggested

235 by Baker and King (2010).

\section{Evaluating species responses to forest loss and forest fragmentation in relation to}

237 compactness of exurban development

238 To evaluate the effects of compactness of exurban development in relation to other factors

239 known to affect birds (i.e., forest loss and forest fragmentation), we used generalized additive

240 models (GAMs) (Hastie \& Tibshirani 1990). GAMs were used to better account for potential

241 non-linear trends between the response and predictor variables (e.g., Guisan et al. 2002; Zuur et 
242 al. 2009). GAMs require fewer assumptions of data distributions and error structures, assuming

243 only that functions are additive and components can be smoothed by local fitting to subsets of

244 the data.

245 The models used adjusted counts for each bird species as dependent variables and

246 compactness of exurban development, proportion of exurban development, proportion of forest,

247 number of forest patches greater than $0.45 \mathrm{ha}$, and forest edge as predictor variables. The latter

248 variables were estimated following Suarez-Rubio et al. (2013). Gaussian errors and an identity

249 link were used and smoothing parameters were automatically selected based on the effective

250 degrees of freedom and a generalized cross validation criterion in R package mgcv (Wood 2001;

251 Wood 2006). We did a multi-model comparison using a stepwise backwards selection process

252 and calculated the Akaike information criterion $\left(\mathrm{AIC}_{i}\right)$ and the $\Delta \mathrm{AIC}_{i}$ to rank models and select a

253 best-fitted model (Zuur et al. 2009). We used the results to strengthen the inference regarding

254 factors affecting birds in forested environments. Models were evaluated based on graphical

255 diagnostic plots and the explanatory power of a model was assessed by examining the amount of

256 the explained deviance. Predictors of the best-fitted model with high significance levels $(p<$

257 0.01) were identified as key factors that have strong effects on bird species.

\section{RESULTS}

\section{Landscape composition and compactness of exurban development around survey stops}

Landscape composition around survey stops changed through time during the time period studied, except for the $21 \%$ of stops that were inside protected areas (Table 1). The inclusion

262 here of MSPA classes that represented associated roads (i.e., Bridge, Branch, and Loop) in

263 addition to scattered isolated pixels (i.e., Islets) in the definition of exurban development differed

264 from other operational definitions of exurban development used in previous work; as a result, the 
265 total amount of development that was classified as exurban was higher for our study than was

266 reported for more restrictive definitions (e.g., Suarez-Rubio et al. 2012a). For both the 400-m

267 and 1-km radius buffers, there was a 6\% increase in exurban development from 1986 to 2009

268 (Table 1).

269 Compactness of exurban development also increased over time (Table 1). For the 400-m

270 radius buffer, compactness increased from $18 \%$ in 1986 to $39 \%$ in 2009 . For the $1-\mathrm{km}$ radius

271 buffer, compactness increased even more, from $11 \%$ in 1986 to $44 \%$ in 2009 . For both extents,

272 the increase was higher between 2000 and 2009 than for any other time period. Compactness was

273 slightly correlated with the amount of exurban development (Pearson's correlation coefficient for

274 400-m buffer: 0.38 , and 1-km buffer: 0.46 ) and not correlated with forest at either extent

275 (Pearson's correlation coefficient for 400-m buffer: -0.15, 1-km buffer: 0.04).

276 Response of bird species to compactness of exurban development

277 Non-parametric locally weighted polynomial regression (loess) models indicated a non-linear

278 relationship between the compactness index and abundance of selected bird species (Fig. 3).

279 Forest species differed in their threshold response to compactness of exurban development (Fig.

280 4). For the $400-m$ radius buffer, only one of the six forest species (i.e. Scarlet Tanager) showed a

281 significant and reliable threshold response to compactness. Although Wood Thrush also

282 responded negatively, the quality of the indicator was less reliable (0.80) (Table 2). In contrast,

283 for the 1-km radius buffer, almost all forest species responded positively and reliably to the

284 compactness of exurban development (Table 2).

285 Forest-edge species also had significant though less consistent threshold responses to

286 compactness of exurban development at both extents (Fig. 4). For the 400-m radius buffer,

287 Eastern Phoebe and Gray Catbird had a significant positive response to the compactness metric, 
288 while Eastern Towhee responded negatively to compactness. For the 1-km radius buffer, Eastern

289 Phoebe, Gray Catbird, and Indigo Bunting responded positively to compactness, with reliability

290 values and change points spanning a wide range of compactness values, similar to the finding for

291 forest birds (e.g., Red-eyed Vireo, Eastern Wood-Pewee; Fig. 4).

292 In general, reliability information was redundant with purity (i.e., species with $\geq 0.95$

293 purity were usually also reliable) (Table 2). In some instances, the direction of the response

294 changed with extent of analysis. Wood Thrush responded positively to compactness of exurban

295 development for the 1-km radius buffer. Although the direction of the response changed for the

$296400-\mathrm{m}$ radius buffer, the indicator was not reliable at this extent (reliability $=0.80$ ). For the other

297 species (i.e. Scarlet Tanager and Eastern Towhee), wide confidence bands and reduced z scores

298 when compared to the reliable extent, highlighted uncertainty when the abundance distributions

299 did not show a clear response. Therefore, where there were differences in the reliability and

300 direction of response at different extents, the 1-km relationships were more reliable.

301 Most species (both forest and forest-edge) had relatively broad bootstrapped change-point

302 distributions indicating that there were not sharp threshold responses to compactness of exurban

303 development (Fig. 4). In addition, the width of the bootstrapped change-point distributions varied

304 between the two buffer distances for only a few species. For example, Eastern Phoebe was one of

305 the few species with a sharp response to compactness, but this occurred only at the 400-m radius 306 buffer.

307 Response of bird species to forest loss and forest fragmentation in relation to compactness 308 of exurban development

309 When forest loss and forest fragmentation were included as predictor variables in addition

310 to the exurban development measures (i.e., proportion and compactness), forest had a highly 
311 significant effect on all forest species modeled and most forest-edge species at the 1-km radius

312 buffer (Table 3). Number of forest patches had a significant influence on Red-eyed Vireo and

313 Scarlet Tanager and forest edge did not affect any of the forest species. The effect of exurban

314 development varied among forest species. Only Red-eyed Vireo was significantly influenced by

315 both proportion of exurban development and compactness of exurban development. Eastern

316 Wood-Pewee and Wood Thrush were influenced by compactness of exurban development,

317 whereas Scarlet Tanager was only influenced by proportion of exurban development.

318 None of the forest-edge species were influenced by compactness of exurban development

319 at the 1-km radius buffer, although Eastern Phoebe, Eastern Towhee, Indigo Bunting, and

320 Northern Cardinal were affected by its proportion. Regarding forest fragmentation, Indigo

321 Bunting and Northern Cardinal were influenced by number of forest patches, whereas Eastern

322 Phoebe, Eastern Towhee, and Gray Catbird were affected by forest edge. Models at the 400-m

323 buffer and for American Redstart and Ovenbird at the 1-km buffer did not converge.

\section{DISCUSSION}

325 Our results suggest that both forest birds and some forest-edge species responded to spatial

326 patterns of exurban development at the landscape extent (1-km radius buffer) (Fig. 4B). Contrary

327 to our prediction, forest birds exhibited a positive response to compactness of exurban

328 development with change points between $21 \%$ and $78 \%$ (Table 2 ). These results indicate that

329 frequency and abundance of forest birds increase as compactness increases. There are a few

330 reasons that could explain this pattern. First, although compactness of exurban development

331 increased over time, these bird species were also increasing in abundance generally in the region

332 (Suarez-Rubio et al. 2013) partly due to forest regrowth (Bowen et al. 2007) and protected areas

333 adjacent to the study area. Second, forest disturbance associated with exurban development may 
334 benefit forest birds, especially forest birds such as American Redstart and Red-eyed Vireo that

335 seem to occur more frequently in early and mid-successional forests and even start to decline as

336 forests mature (Holmes \& Sherry 2001; Hunt 1998). Lastly, even though forest decreased around

337 survey stops, forest cover was nonetheless above the minimum amount of habitat necessary for

338 the persistence of forest birds ( $>30 \%$; Andrén 1994; Betts et al. 2007; Radford et al. 2005;

339 Suarez-Rubio et al. 2013; Zuckerberg \& Porter 2010).

340 When the effects of compactness of exurban development were assessed in relation to

341 forest loss and forest fragmentation, proportion of forest had a highly significant effect compared

342 to compactness in most cases (Table 3). This indicates that for forest birds, proportion of forest at

343 the landscape extent may be more important than exurban development. However, proportion of

344 exurban development and compactness also had a significant effect which suggests that if

345 proportion of exurban development or compactness continues this would inevitably lead to the

346 loss of forest species.

347 Surprisingly, Indigo Bunting and Gray Catbird (i.e., forest-edge species) also responded

348 positively to compactness of exurban development at the landscape extent with change points

349 similar to those exhibited by forest birds (Table 2, Fig. 4B). Although Indigo Bunting is known

350 for its strong preference for edges, and surely human habitat modification (e.g., clearing of

351 woods) increases suitable habitat for buntings (Payne 2006), bunting numbers have declined in

352 eastern North America since the last quarter of the twentieth century (Sauer et al. 2014). These

353 declines have been associated with increasing levels of brood parasitism and predation that occur

354 in fragmented habitats (Donovan \& Flather 2002; Robinson et al. 1995) but also to forest

355 regrowth which has reduced shrubby habitats that they tend to use (DeGraaf \& Yamasaki 2003).

356 It is important to note that when forest loss and forest fragmentation were also considered, the 
357 effect of compactness was not significant and proportion of forest and exurban development had

358 a greater influence. This suggests that buntings may be more sensitive to habitat quantity than the

359 spatial pattern of exurban development.

360 Gray Catbird is frequently associated with suburbia and also prefers early successional

361 habitats, and shrubs around houses have probably increased the availability of breeding habitat

362 for this species (Smith et al. 2011b). Although compact exurban development may minimize the

363 disturbance associated with domestic predators introduced in exurban areas that usually prey

364 directly on nests (Balogh et al. 2011; Lepczyk et al. 2003; Lumpkin et al. 2012), the effects of

365 compactness diminished when forest loss and fragmentation were also taken into account at the

366 landscape extent.

367 At the local extent (i.e., 400-m radius buffer), Scarlet Tanager responded negatively,

368 whereas Gray Catbird responded positively to compactness of exurban development, with both

369 exhibiting gradual responses (Fig. 4A). Scarlet Tanager is an interior forest species that is very

370 sensitive to forest fragmentation (Rosenberg et al. 1999). In a previous study, this species was

371 found to have a negative response to the amount of exurban development at very low levels

372 (Suarez-Rubio et al. 2013). Thus, Scarlet Tanager appears to be negatively affected by exurban

373 development regardless of its spatial configuration which was also the case for the landscape

374 extent. The positive response of Gray Catbird to compactness of exurban development perhaps

375 indicates that predation pressure by introduced domestic predators in exurban areas (Lepczyk et

376 al. 2003; Lumpkin et al. 2012) affects catbirds at the local extent. Exurban areas have large

377 numbers of non-native plant species (Gavier-Pizarro et al. 2010; Lenth et al. 2006; Maestas et al.

378 2003), and there is some evidence that nests in exotic shrubs are twice as likely to be depredated 
379 and suffer higher rates of nest failure than nests in native shrubs (Borgmann \& Rodewald 2004),

380 although this is not always the case (Meyer et al. 2015).

381 Interestingly, most forest birds did not exhibit threshold responses to compactness of

382 exurban development at the local extent. This difference in response at the local and landscape

383 extent suggests that the effects of compactness of exurban development are scale dependent.

384 Smith et al. (2011a) demonstrated that effects of fragmentation change with the extent of

385 analysis because ecological processes (e.g. predation) act at different spatial scales. Thus, the

386 effects of compactness of exurban development might be associated with the size of the

387 disturbance zone. Other studies have found an ecological effect zone of up to $200 \mathrm{~m}$ from

388 exurban homes in which avian densities were altered (Glennon \& Kretser 2013; Odell \& Knight

389 2001).

390 Our results reveal that the responses of forest birds varied, but extended well beyond a

391 200-m radius. When considering a 400-m zone of influence, most forest birds did not respond

392 significantly to the spatial pattern of exurban development. However, the spatial compactness of

393 development was associated with a positive response at the 1-km zone for nearly all forest bird

394 species. Previous studies have shown that forest birds are very sensitive to the proportion of

395 exurban development (e.g., Pidgeon et al. 2007; Suarez-Rubio et al. 2013). Our results show that

396 forest birds are also sensitive to its spatial configuration at large extents. In general, if exurban

397 development occurs in the landscape, it affects the entire 400-m radius buffer regardless of its

398 arrangement, but by aggregating exurban development within the 1-km radius buffer, safe zones

399 were retained that could support forest birds and the effects of compactness of exurban

400 development were reduced. 
By assessing the spatial pattern of exurban development for the multiple images, we were

402 able to capture the dynamics of landscape change over time (Table 1) as was also done

403 previously for the conterminous United States (e.g., Mockrin et al. 2012; Pidgeon et al. 2014).

404 As exurban areas grew, scattered, isolated exurban development became more contiguous and

405 clumped. Thus, our results demonstrate the effects of the spatial pattern of exurban development

406 within the larger context of forest habitat loss. At the level of individual survey stops, the

407 positive but weak correlation between exurban development and compactness indicates that there

408 is variance in spatial configuration that is independent from the overall amount of exurban

409 development.

410 Although the total amount of exurban development around survey stops increased

411 compared to previous operational definitions (Suarez-Rubio et al. 2013), forest loss and forest

412 fragmentation did not vary when definitions were compared (Appendix 1). Thus, by including

413 both isolated and scattered housing units and associated roads into our definition, we were able

414 to reflect the substantial expansion of exurban development that has occurred in the region (e.g.,

415 Suarez-Rubio et al. 2012a). In addition, by considering the effects of the spatial pattern of

416 exurban development besides forest loss and forest fragmentation, we identified the importance

417 of compactness in light of other factors that are known to affect forest birds.

418 Nonetheless, some caveats arise. The use of bird counts along BBS routes may not fully

419 reflect occurrence and abundance of more sensitive species such as Kentucky Warbler. Although

420 counts along roadsides have been shown to be representative of changes occurring over much

421 broader areas (Keller \& Scallan 1999), our findings cannot be generalized beyond the range of

422 housing density included in this study (e.g., to wilder or more urbanized areas). In addition, the 
423 compactness index was developed to assess the clumpiness of exurban housing and assumed

424 presence of housing units thus it is not suitable for comparison to areas without development.

425 A critical unknown of exurban growth is the possible cumulative impacts on wildlife.

426 Evaluating potential cumulative impacts requires an enhanced understanding of both the density

427 and patterns of residential development and of the distinct effects of these two components of

428 landscape change (Pidgeon et al. 2014; Theobald et al. 1997). We have taken a first step by

429 identifying the extent at which forest and forest-edge species respond to the spatial patterning of

430 exurban development and highlight that the positive response of forest birds to compactness at

431 the larger extent should be taken cautiously because this could represent a systematic trajectory

432 of decline (Pidgeon et al. 2014) and if exurban growth continues to increase, as trends suggest,

433 this will lead towards more contagious development which could be highly detrimental to bird

434 diversity. Thus, management efforts should try to concentrate development away from ecological

435 sensitive areas, create or maintain safe zones, and minimize forest loss or fragmentation (i.e.,

436 increase compactness) to support forest birds.

\section{ACKNOWLEDGEMENTS}

438 The authors thank thousands of volunteers who have collected Breeding Bird Survey Data and

439 D. Ziolkowski and K. Pardieck (USFWS) for providing the bird data, the topographic maps, and

440 the description of the BBS stops. S. Wilson and R. Hildebrand provided helpful analytic advice.

441 We thank C. Elphick, C. Rittenhouse, and anonymous reviewers for comments that greatly

442 improved the manuscript. 


\section{REFERENCES}

444 Adams JB, Smith MO, and Johnson PE. 1986. Spectral mixture modeling: a new analysis of rock 445 and soil types at the Viking Lander 1 site. Journal of Geophysical Research 91:8098-8112. DOI 10.1029/JB091iB08p08098

Andrén H. 1994. Effects of habitat fragmentation on birds and mammals in landscapes with different proportions of suitable habitat: a review. OIKOS 71:355-366.

Alberti M, and Marzluff JM. 2004. Ecological resilience in urban ecosystems: linking urban patterns to human and ecological functions. Urban Ecosystems 7:241-265. DOI 10.1023/B:UECO.0000044038.90173.c6

Baker ME, and King RS. 2010. A new method for detecting and interpreting biodiversity and ecological community thresholds. Methods in Ecology and Evolution 1:25-37. DOI 10.1111/j.2041-210X.2009.00007.x

Balogh AL, Ryder TB, and Marra PP. 2011. Population demography of Gray Catbirds in the suburban matrix: sources, sinks and domestic cats. Journal of Ornithology 152:717-726. DOI 10.1007/s10336-011-0648-7

Berube A, Singer A, Wilson JH, and Frey WH. 2006. Finding exurbia: America's fast-growing communities at the metropolitan fringe. The Brookings Institution, Living Cities Census Series:1-47.

Betts MG, Forbes GJ, and Diamond AW. 2007. Thresholds in songbird occurrence in relation to landscape structure. Conservation Biology 21:1046-1058. DOI: 10.1111/j.15231739.2007.00723.x

Borgmann KL, and Rodewald AD. 2004. Nest predation in an urbanizing landscape: the role of exotic shrubs. Ecological Applications 14:1757-1765. DOI 10.1890/03-5129 
466 Bowen ME, McAlpine CA, House APN, and Smith GC. 2007. Regrowth forests on abandoned 467 agricultural land: a review of their habitat values for recovering forest fauna. Biological 468 of Zoology 81:195-202. DOI 10.1139/z02-237

Brown DG, Johnson KM, Oveland TR, and Theobald DM. 2005. Rural land-use trends in the conterminous United States, 1950-2000. Ecological Applications 15:1851-1863. DOI

Brown ML, Donovan TM, Schwenk WS, and Theobald DM. 2014. Predicting impacts of future human population growth and development on occupancy rates of forest-dependent birds. Biological Conservation 170:311-320. DOI 10.1016/j.biocon.2013.07.039

Casey JM, Wilson ME, Hollingshead N, and Haskell DG. 2009. The effects of exurbanization on bird and macroinvertebrate communities in deciduous forests on the Cumberland Plateau, Tennessee. International Journal of Ecology 2009:10 pages. DOI 10.1155/2009/539417

Chace JFWJJ, Cruz A, Prather JW, and Swanson HM. 2003. Spatial and temporal activity patterns of the brood parasitic brown-headed cowbird at an urban/wildland interface. Landscape and Urban Planning 64:173-190. DOI 10.1016/S0169-2046(02)00220-7

Cleveland WS, and Devlin SJ. 1988. Locally-weighted regression: an approach to regression analysis by local fitting. Journal of the American Statistical Association 83:596-610. DOI $10.1080 / 01621459.1988 .10478639$

Dale V, Archer S, Chang M, and Ojima D. 2005. Ecological impacts and mitigation strategies for rural land management. Ecological Applications 15:1879-1892. DOI 10.1890/03-5330 
488 Daniels T. 1999. When city and country collide: managing growth in the metropolitan fringe.

489 Washington, D.C., USA: Island Press.

490 Dauphiné N, and Cooper RJ. 2009. Impacts of free-ranging domestic cats (Felis catus) on birds

491 in the United States: a review of recent research with conservation and management

492 recommendations In: Rich TD, Arizmendi C, Demarest DW, and Thompson C, editors.

493 Proceedings of the Fourth International Partners in Flight Conference. p 205-219.

494 Davis CR, and Hansen AJ. 2011. Trajectories in land use change around U.S. National Parks and challenges and opportunities for management. Ecological Applications 21:3299-3316. DOI $10.1890 / 10-2404.1$

497

498

499

500

501

502

503

504

505

506

507

508

509

510

DeGraaf RM, and Yamasaki M. 2003. Options for managing early-successional forest and shrubland bird habitats in the northeastern United States. Forest Ecology and Management 185:179-191. DOI 10.1016/S0378-1127(03)00254-8

Donnelly R, and Marzluff JM. 2006. Relative importance of habitat quantity, structure, and spatial pattern to birds in urbanizing environments. Urban Ecosystems 9:99-117. DOI 10.1007/s11252-006-7904-2

Donovan TM, and Flather CH. 2002. Relationships among North American songbird trends, habitat fragmentation, and landscape occupancy. Ecological Applications 12:364-374. DOI 10.1890/1051-0761(2002)012[0364:RANAST]2.0.CO;2

Engels TM, and Sexton CW. 1994. Negative correlation of Blue jays and Golden-cheeked Warblers near an urbanizing area. Conservation Biology 8:286-290. DOI 10.1046/j.15231739.1994.08010286.x

Erskine AJ. 1978. The first ten years of the cooperative breeding bird survey in Canada. Canadian Wildlife Service Report Series 42:1-61. 
511 Fahrig L. 1997. Relative effects of habitat loss and fragmentation on population extinction. The

512 Journal of Wildlife Management 61:603-610.

513 Fraterrigo JM, and Wiens JA. 2005. Bird communities of the Colorado Rocky Mountains along a

514 gradient of exurban development. Landscape and Urban Planning 71:263-275. DOI

$515 \quad$ 10.1016/j.landurbplan.2004.03.008

516 Friesen LE, Eagles PFJ, and Mackay RJ. 1995. Effects of residential development on forest-

517 dwelling Neotropical migrant songbirds. Conservation Biology 9:1408-1414. DOI

518 10.1046/j.1523-1739.1995.09061408.x

519 Gagné SA, and Fahrig L. 2010. The trade-off between housing density and sprawl area:

520 minimising impacts to forest breeding birds. Basic and Applied Ecology 11:723-733. DOI

$521 \quad 10.1016 /$ j.baae.2010.09.001

522 Gavier-Pizarro GI, Radeloff VC, Stewart SI, Huebner CD, and Keuler NS. 2010. Housing is positively associated with invasive exotic plant species richness in New England, USA. Ecological Applications 20:1913-1925. DOI 10.1890/09-2168.1

Gelman A, Carlin JB, Stern HS, and Rubin DB. 2004. Bayesian data analysis. Boca Raton, 526 Florida, USA: Chapman and Hall/CRC.

527 Glennon MJ, and Kretser HE. 2013. Size of the ecological effect zone associated with exurban 528 development in the Adirondack Park, NY. Landscape and Urban Planning 112:10-17. DOI 10.1016/j.landurbplan.2012.12.008

530 Gonzalez-Abraham CE, Radeloff VC, Hammer RB, Hawbaker TJ, Stewart SI, and Clayton MK.

5312007 . Building patterns and landscape fragmentation in northern Wisconsin, USA.

532 Landscape Ecology 22:217-230. DOI 10.1007/s10980-006-9016-Z 
533 Gude PH, Hansen AJ, Rasker R, and Maxwell B. 2006. Rates and drivers of rural residential

534 development in the Greater Yellowstone. Landscape and Urban Planning 77:131-151.

535 DOI 10.1016/j.landurbplan.2005.02.004

536 Guisan A, Edwards TC, Jr., and Hastie T. 2002. Generalized linear and generalized additive models in studies of species distributions: setting the scene. Ecological Modelling 157:89100.

Hagan JM, III. 1993. Decline of the Rufous-sided Towhee in the Eastern United States. The Auk 110:863-874.

541

542

543

544

545

546

547

548

549

550

551

552

553

554

555

Hammer RB, Stewart SI, Winkler RL, Radeloff VC, and Voss PR. 2004. Characterizing dynamic spatial and temporal residential density patterns from 1940 to 1990 across the North Central United States. Landscape and Urban Planning 69:183-199. DOI 10.1016/j.landurbplan.2003.08.011

Hansen AJ, Knight RL, Marzluff JM, Powell S, Brown K, Gude PH, and Jones K. 2005. Effects of exurban development on biodiversity: patterns, mechanisms, and research needs. Ecological Applications 15:1893-1905. DOI 10.1890/05-5221

Hastie TJ, and Tibshirani RJ. 1990. Generalized Additive Models. 1st ed. London, UK: Chapman \& Hall.

Holmes RT, and Sherry TW. 2001. Thirty-year bird population trends in an unfragmented temperate deciduous forest: importance of habitat change. The Auk 118:589-609. DOI $10.2307 / 4089923$

Huang Q, Robinson D, and Parker D. 2014. Quantifying spatial-temporal change in land-cover and carbon storage among exurban residential parcels. Landscape Ecology 29:275-291. DOI 10.1007/s10980-013-9963-0 
556 Hunt PD. 1998. Evidence from a landscape population model of the importance of early

557 successional habitat to the American Redstart. Conservation Biology 12:1377-1389.

558 Keller CME, and Scallan JT. 1999. Potential roadside biases due to habitat changes along

559 breeding bird survey routes. Condor 101:50-57. DOI 10.2307/1370445

560 Kendall WL, Peterjohn BG, and Sauer JR. 1996. First time observer effects in the North

561 American Breeding Bird Survey. The Auk 113:823-829. DOI 10.2307/4088860

562 Kirk RW, Bolstad PV, and Manson SM. 2012. Spatio-temporal trend analysis of long-term

563 development patterns (1900-2030) in a Southern Appalachian County. Landscape and

$564 \quad$ Urban Planning 104:47-58. DOI 10.1016/j.landurbplan.2011.09.008

565 Kluza DA, Griffin CR, and Degraaf RM. 2000. Housing developments in rural New England:

566 effects on forest birds. Animal Conservation 3:15-26. DOI 10.1111/j.1469-

567 1795.2000.tb00083.x

Krementz DG, and Powell LA. 2000. Breeding season demography and movements of Eastern Towhees at the Savanna River site, South Carolina. Wilson Bulletin 112:243-248. DOI 10.1676/0043-5643(2000)112[0243:BSDAMO]2.0.CO;2

Lamb RF. 1983. The extent and form of exurban sprawl. Growth and Change 14:40-47. DOI 10.1111/j.1468-2257.1983.tb00395.x

573

574

575

576

577

578
Lang JD, Powell LA, Krementz DG, and Conroy MJ. 2002. Wood Thrush movements and habitat use: effects of forest management for Red-cockaded Woodpeckers. The Auk 119:109-124. DOI 10.1676/09-105.1

Lenth BA, Knight RL, and Gilgert WC. 2006. Conservation value of clustered housing developments. Conservation Biology 20:1445-1456. DOI 10.1111/j.15231739.2006.00491.x 
579 Lepczyk CA, Mertig, A. G., and Liu aJG. 2003. Landowners and cat predation across rural-to580 urban landscapes. Biological Conservation 115:191-201. DOI dx.doi.org/10.1016/S0006$581 \quad 3207(03) 00107-1$

582 Lepczyk CA, Mertig AG, and Liu JG. 2004. Assessing landowner activities related to birds 583 across rural-to-urban landscapes. Environmental Management 33:110-125. DOI

$584 \quad 10.1007 / \mathrm{s} 00267-003-0036-\mathrm{Z}$

585 Leu M, Hanser SE, and Knick ST. 2008. The human footprint in the west: a large-scale analysis of anthropogenic impacts. Ecological Applications 18:1119-1139. DOI 10.1890/07-0480.1

587

588

589

590

591

592

593

594

595

596

597

598

599

Lichstein JW, Simons TR, and Franzreb KE. 2002. Landscape effects on breeding songbird abundance in managed forests. Ecological Applications 12:836-857. DOI 10.1890/10510761(2002)012[0836:leobsa]2.0.co;2

Link WA, and Barker RJ. 2010. Bayesian inference with ecological applications. London, UK: Academic Press.

Lumpkin HA, Pearson SM, and Turner MG. 2012. Effects of climate and exurban development on nest predation and predator presence in the southern Appalachian Mountains (U.S.A.). Conservation Biology 26:679-688. DOI 10.1111/j.1523-1739.2012.01851.x

Lunn DJ, Thomas A, Best N, and Spiegelhalter D. 2000. WinBUGS a Bayesian modeling framework: concepts, structure and extensibility. Statistics and Computing 10:325-337. DOI 10.1023/A:1008929526011

Maestas JD, Knight RL, and Gilgert WC. 2003. Biodiversity across a rural land-use gradient. Conservation Biology 17:1425-1434. DOI 10.1046/j.1523-1739.2003.02371.x 
600 Marzluff JM. 2001. Worldwide urbanization and its effects on birds. In: Marzluff JM, Bowman

601 R, and Donnelly R, eds. Avian ecology and conservation in an urbanizing world. Boston, 602 USA: Kluwer Academic Publishers, 19-47.

603 Mazerolle DF, and Hobson KA. 2004. Territory size and overlap in male Ovenbirds: contrasting 604 a fragmented and contiguous boreal forest. Canadian Journal of Zoology 82:1774-1781. $605 \quad$ DOI $10.1139 / \mathrm{z} 04-175$

606 McKenzie P, Cooper A, McCann T, and Rogers D. 2011. The ecological impact of rural building 607 on habitats in an agricultural landscape. Landscape and Urban Planning 101:262-268. DOI $608 \quad$ 10.1016/j.landurbplan.2011.02.031

609 Merenlender AM, Reed SE, and Heise KL. 2009. Exurban development influences woodland $610 \quad$ bird composition. Landscape and Urban Planning 92:255-263. DOI

$611 \quad$ 10.1016/j.landurbplan.2009.05.004

612 Meyer LM, Schmidt KA, and Robertson BA. 2015. Evaluating exotic plants as evolutionary 613 traps for nesting Veeries. The Condor 117:320-327. DOI 10.1650/CONDOR-14-101.1

614 Mikusiñski G, Gromadzki M, and Chylarecki P. 2001. Woodpeckers as indicators of forest bird 615 diversity. Conservation Biology 15:208-217. DOI 10.1111/j.1523-1739.2001.99236.x

616 Miller SG, Knight RL, and Miller CK. 1998. Influence of recreational trails on breeding bird 617 communities. Ecological Applications 8:162-169. DOI 10.1890/1051-

618 0761(1998)008[0162:IORTOB]2.0.CO;2

619 Mockrin MH, Stewart SI, Radeloff VC, Hammer RB, and Johnson KM. 2012. Spatial and 620 temporal residential density patterns from 1940 to 2000 in and around the Northern Forest 621 of the Northeastern United States. Population and Environment 34:400-419. DOI 622 $10.1007 / \mathrm{s} 11111-012-0165-5$ 
623 Nelson AC. 1992. Characterizing exurbia. Journal of Planning Literature 6:350-368. DOI

$624 \quad 10.1177 / 088541229200600402$

625 NIFC (National Interagency Fire Center). 2013. Wildland fire statistics. Available at 626 www.nifc.gov (accessed 5 March 2014).

627 Odell EA, and Knight RL. 2001. Songbird and medium-sized mammal communities associated 628 with exurban development in Pitkin County, Colorado. Conservation Biology 15:11431150. DOI 10.1046/j.1523-1739.2001.0150041143.x

630 Odell EA, Theobald DM, and Knight RL. 2003. Incorporating ecology into land use planning:

631 the songbirds' case for clustered development. Journal of the American Planning

632 Association 69:72-82. DOI 10.1080/01944360308976294

633 Payne RB. 2006. Indigo Bunting (Passerina cyanea) The Birds of North America Online.

634 Cornell Lab of Ornithology Available at

635 http://bna.birds.cornell.edu.bnaproxy.birds.cornell.edu/bna/species/004 (accessed 28 April 636 2014).

637 Pendall R. 2003. Sprawl without Growth: the Upstate Paradox. The Brookings Institution, Center 638 on Urban and Metropolitan Policy Survey Series, 11 pp.

639 Peterjohn BG, and Sauer JR. 1994. Population trends of woodland birds from the North 640 American Breeding Bird Survey. Wildlife Society Bulletin 22:155-164.

641 Pidgeon AM, Flather CH, Radeloff VC, Lepczyk CA, Keuler NS, Wood EM, Stewart SI, and 642 Hammer RB. 2014. Systematic temporal patterns in the relationship between housing 643 development and forest bird biodiversity. Conservation Biology 28:1291-1301. DOI $644 \quad 10.1111 /$ cobi.12291 
645 Pidgeon AM, Radeloff VC, Flather CH, Lepczyk CA, Clayton MK, Hawbaker TJ, and Hammer 646 RB. 2007. Associations of forest bird species richness with housing and landscape patterns 647 across the USA. Ecological Applications 17:1989-2010. DOI dx.doi.org/10.1890/06$648 \quad 1489.1$

649 Poole AE. 2005. The Birds of North America Online Cornell Laboratory of Ornithology $650 \quad$ Available at http://bna.birds.cornell.edu.bnaproxy.birds.cornell.edu/BNA/ (accessed 10 $651 \quad$ July 2012).

652 R Development Core Team. 2013. R: a language and environment for statistical computing 653 http://www.R-project.org. v 3.0.1 ed. R Foundation for Statistical Computing, Vienna, $654 \quad$ Austria.

655 Radeloff VC, Hammer RB, Stewart SI, Fried JS, Holcomb SS, and McKeefry JF. 2005. The 656 wildland-urban interface in the United States. Ecological Applications 15:799-805. DOI dx.doi.org/10.1890/04-1413

Riley SPD, Sauvajot RM, Fuller TK, York EC, Kamradt DA, Bromley C, and Wayne RK. 2003. Effects of urbanization and habitat fragmentation on bobcats and coyotes in southern California. Conservation Biology 17:566-576. DOI 10.1046/j.1523-1739.2003.01458.x Service.

664 Robinson SK, Thompson III FR, Donovan TM, Whitehead DR, and Faaborg J. 1995. Regional 665 forest fragmentation and the nesting success of migratory birds. Science 267:1987-1990. 
666 Rosenberg KV, Lowe JD, and Dhondt AA. 1999. Effects of forest fragmentation on breeding 667 tanagers: a continental perspective. Conservation Biology 13:568-583. DOI

668 10.1046/j.1523-1739.1999.98020.x

669 Sampson N, and DeCoster L. 2000. Forest fragmentation: implications for sustainable private 670 forests. Journal of Forestry 98:4-8.

671 Sauer JR, Fallon JE, and Johnson R. 2003. Use of North American Breeding Bird Survey data to 672 estimate population change for bird conservation regions. The Journal of Wildlife Management 67:372-389.

674

675

676

677

678

679

680

681

682

683

684

685

686
Sauer JR, Hines JE, Fallon JE, Pardieck KL, Ziolkowski DJJ, and Link WA. 2014. The North American Breeding Bird Survey, Results and Analysis 1966 - 2012. Version 02.19.2014 Available at http://www.mbr-pwrc.usgs.gov/bbs/bbs.html (accessed 28 April 2014).

Sauer JR, Pendleton GW, and Orsillo S. 1995. Mapping of bird distributions from point count surveys. In: Ralph CJ, Sauer JR, and Droege S, editors. General Technical Report PSWGTR-149. Pacific Southwest Research Station: USDA Forest Service. p 151- 160.

Seto KC, Güneralp B, and Hutyra LR. 2012. Global forecasts of urban expansion to 2030 and direct impacts on biodiversity and carbon pools. Proceedings of the National Academy of Sciences 109:16083-16088. DOI 10.1073/pnas.1211658109

Sherry TW, and Holmes RT. 1997. American Redstart (Setophaga ruticilla) The Birds of North America Online. Cornell Lab of Ornithology. Available at http://bna.birds.cornell.edu.bnaproxy.birds.cornell.edu/bna/species/277 (accessed 10 July 2012). 
687 Smith AC, Fahrig L, and Francis CM. 2011a. Landscape size affects the relative importance of 688 habitat amount, habitat fragmentation, and matrix quality on forest birds. Ecography 689 34:103-113. DOI 10.1111/j.1600-0587.2010.06201.x

690

691

692

693

694

695

696

697

698

699

700

701

702

703

704

705

706

707

Smith RJ, Hatch MI, Cimprich DA, and Moore FR. 2011b. Gray Catbird (Dumetella carolinensis).The Birds of North America Online. Cornell Lab of Ornithology. Available at http://bna.birds.cornell.edu.bnaproxy.birds.cornell.edu/bna/species/167 (accessed 29 April 2014).

Soille P. 2003. Morphological image analysis: principles and applications. Berlin, Germany: Springer-Verlag.

Suarez-Rubio M, Lookingbill TR, and Elmore AJ. 2012a. Exurban development from 1986 to 2009 surrounding the District of Columbia, USA. Remote Sensing of Environment 124:360-370. DOI 10.1016/j.rse.2012.03.029

Suarez-Rubio M, Lookingbill TR, and Wainger LA. 2012b. Modeling exurban development near Washington, DC, USA: comparison of a pattern-based model and a spatially-explicit econometric model. Landscape Ecology 27:1047-1061. DOI 10.1007/s10980-012-9760-1

Suarez-Rubio M, Renner SC, and Leimgruber P. 2011. Influence of exurban development on bird species richness and diversity. Journal of Ornithology 152:461-471. DOI 10.1007/s10336-010-0605-X

Suarez-Rubio M, Wilson S, Leimgruber P, and Lookingbill T. 2013. Threshold responses of forest birds to landscape changes around exurban development. PLoS One 8:e67593. DOI 10.1371/journal.pone.0067593 
708 Tewksbury JJ, Hejl SJ, and Martin TE. 1998. Breeding productivity does not decline with

709 increasing fragmentation in a western landscape. Ecology 79:2890-2903. DOI

710 10.1890/0012-9658(1998)079[2890:BPDNDW]2.0.CO;2

711 Theobald DM. 2001. Land use dynamics beyond the American urban fringe. Geographical 712 Review 91:544-564. DOI 10.1111/j.1931-0846.2001.tb00240.x

713 Theobald DM, Miller JR, and Hobbs NT. 1997. Estimating the cumulative effects of 714 development on wildlife habitat. Landscape and Urban Planning 39:25-36. DOI 10.1016/S0169-2046(97)00041-8

716 U.S. Census Bureau. 2013. State and County quick facts. Available at http://quickfacts.census.gov (accessed 2 January 2014).

718 U.S. NABCI Committee. 2009. The State of the Birds, United States of America, 2009.

719 Washington, D.C.: U.S. Department of the Interior.

720 Vogt P, Riitters K, Estreguil C, Kozak J, Wade T, and Wickham J. 2007. Mapping spatial

721 patterns with morphological image processing. Landscape Ecology 22:171-177. DOI

722 $10.1007 / \mathrm{s} 10980-006-9013-2$

723 Wood SN. 2001. mgcv: GAMs and Generalized Ridge Regression for R. R News 1:20-25.

724 Wood SN. 2006. Generalized Additive Models: an introduction with R. London, UK: Chapman 725 and Hall/CRC.

726 Zuckerberg B, and Porter WF. 2010. Thresholds in the long-term responses of breeding birds to 727 forest cover and fragmentation. Biological Conservation 143:952-962. DOI

$728 \quad 10.1016 /$ j.biocon.2010.01.004

729 Zuur AF, Ieno EN, Walker NJ, Saveliev AA, and Smith GM. 2009. Mixed effects models and $730 \quad$ extensions in ecology with R. New York, USA: Springer. 
Figure 1 (on next page)

Study area (shaded region).

Circles represent 125 North American Breeding Bird Survey (BBS) routes that were uniformly selected from routes. 


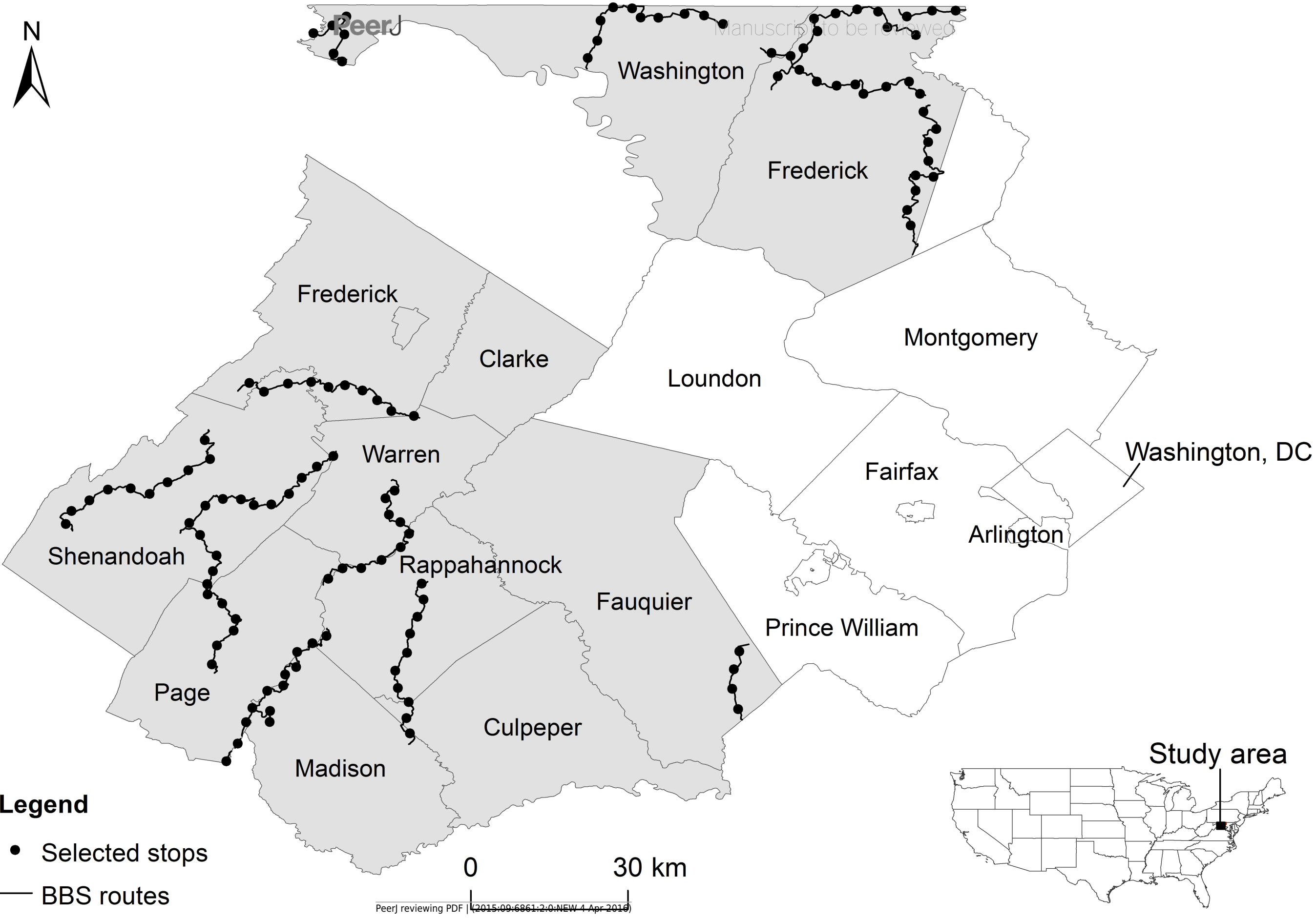


Figure 2 (on next page)

Example of morphological spatial pattern analysis (MSPA) output used to derive level of compactness of exurban development around surrounding areas of selected BBS stops.

The illustration shows compactness around 1-km radius buffer of three different BBS stops in 2009 with similar amount of exurban development $(20.0 \pm 1.3 \%)$ among the three landscapes. 
Compactness: $12 \%$

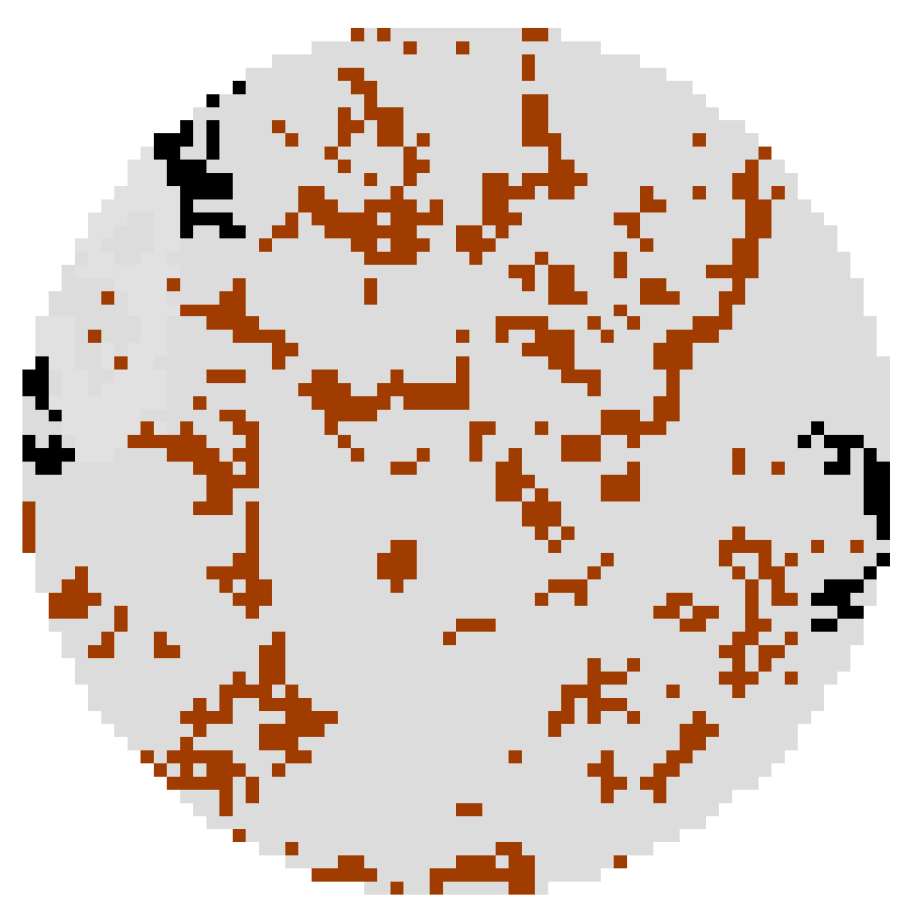

\section{Legend}

Exurban development islets
$52 \%$

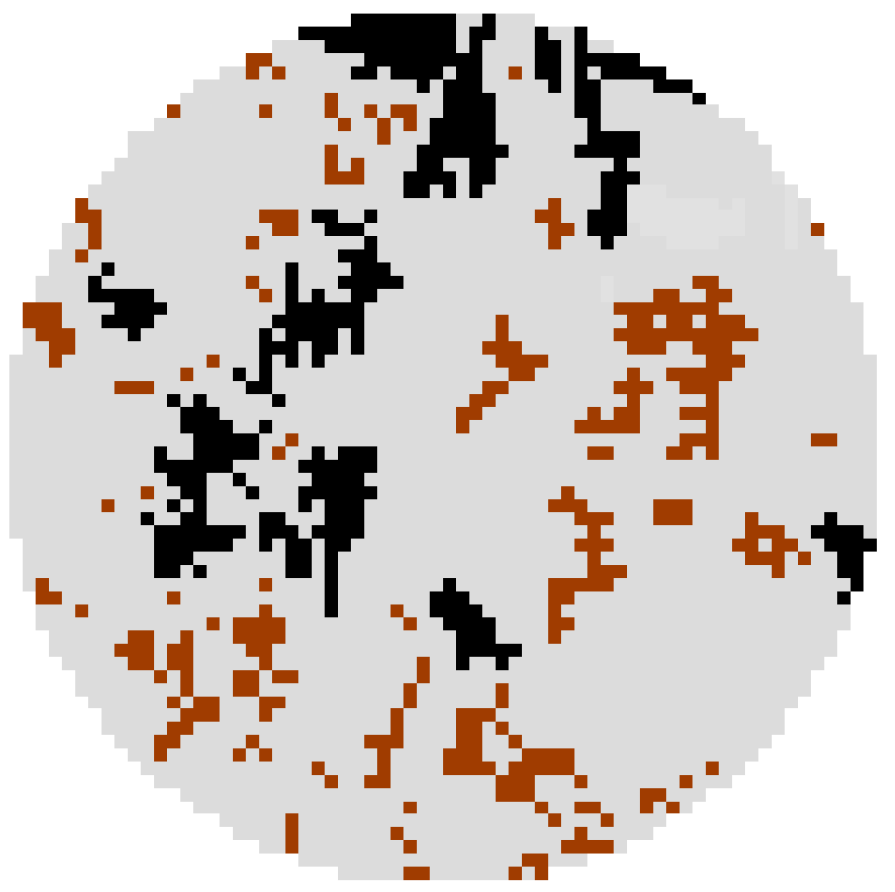

$83 \%$

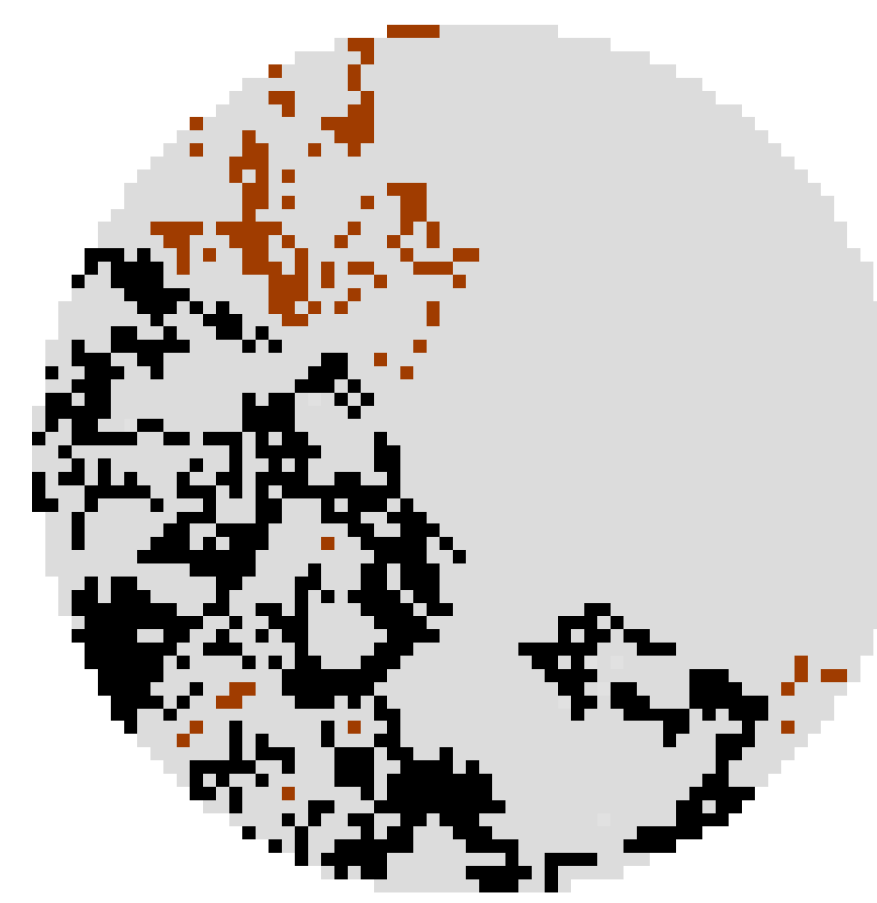




\section{Figure 3 (on next page)}

Relationships between compactness of exurban development and adjusted counts of selected bird species for (A) 400-m and (B) 1-km radius buffer around BBS stops. 
A. PeerJ

American Redstart

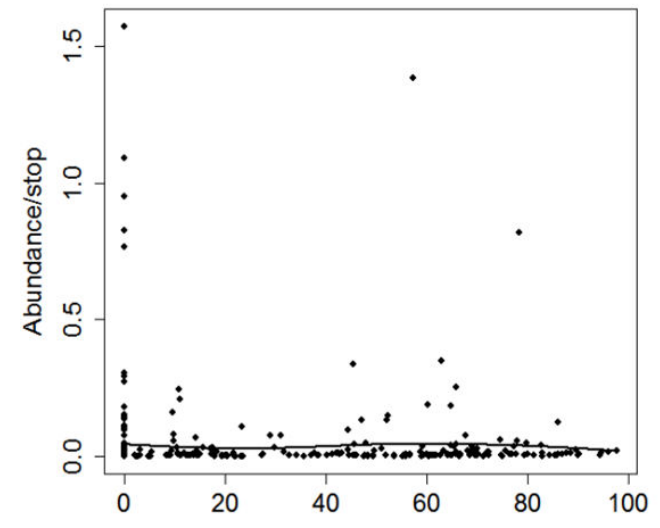

Red-eyed Vireo

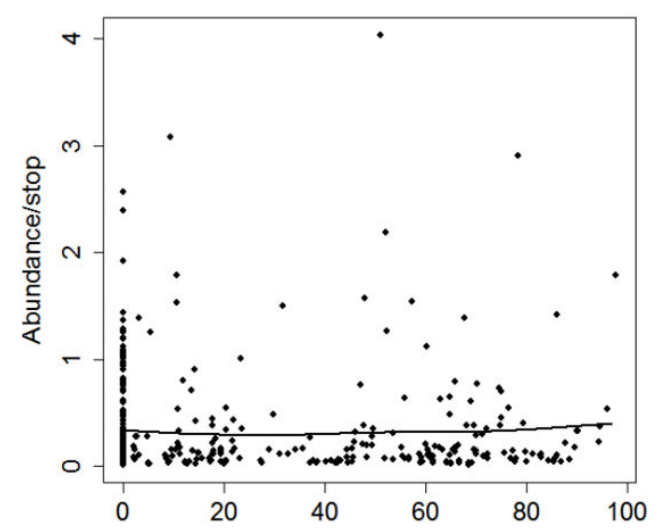

Eastern Phoebe

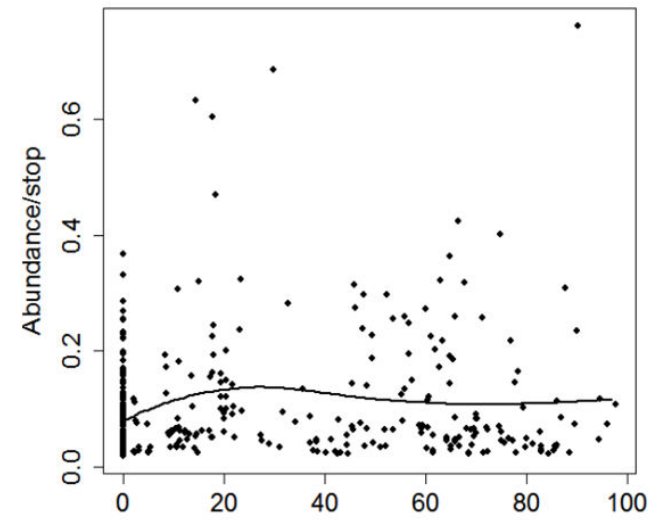

Indigo Bunting

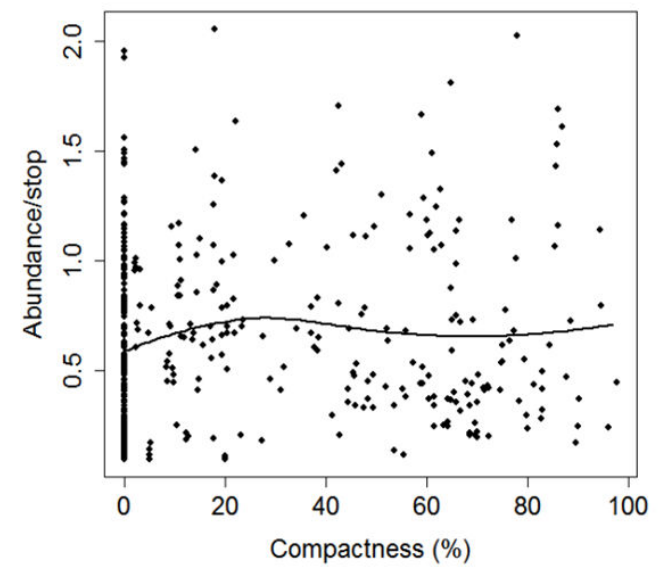

Manuscript to be reviewed

Ovenbird

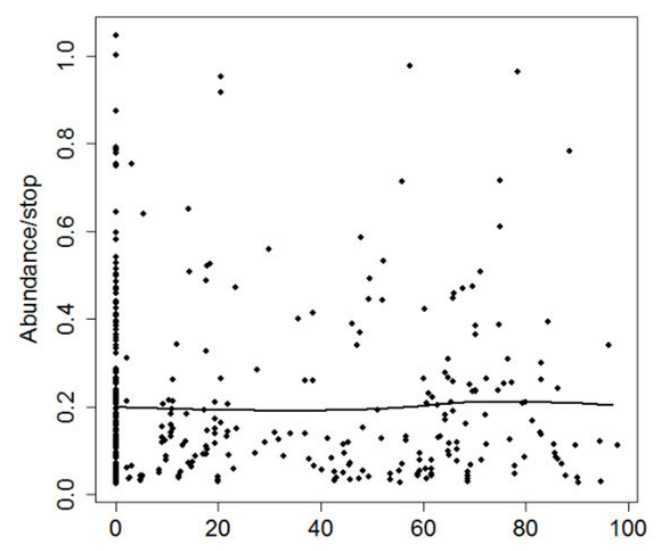

Scarlet Tanager

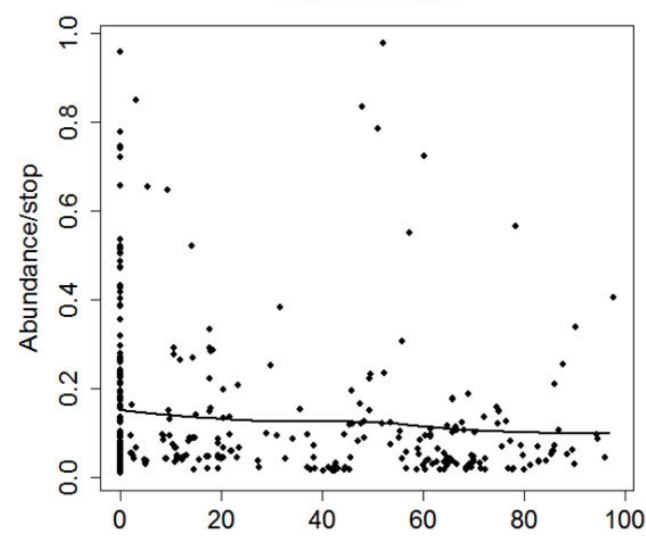

Eastern Towhee
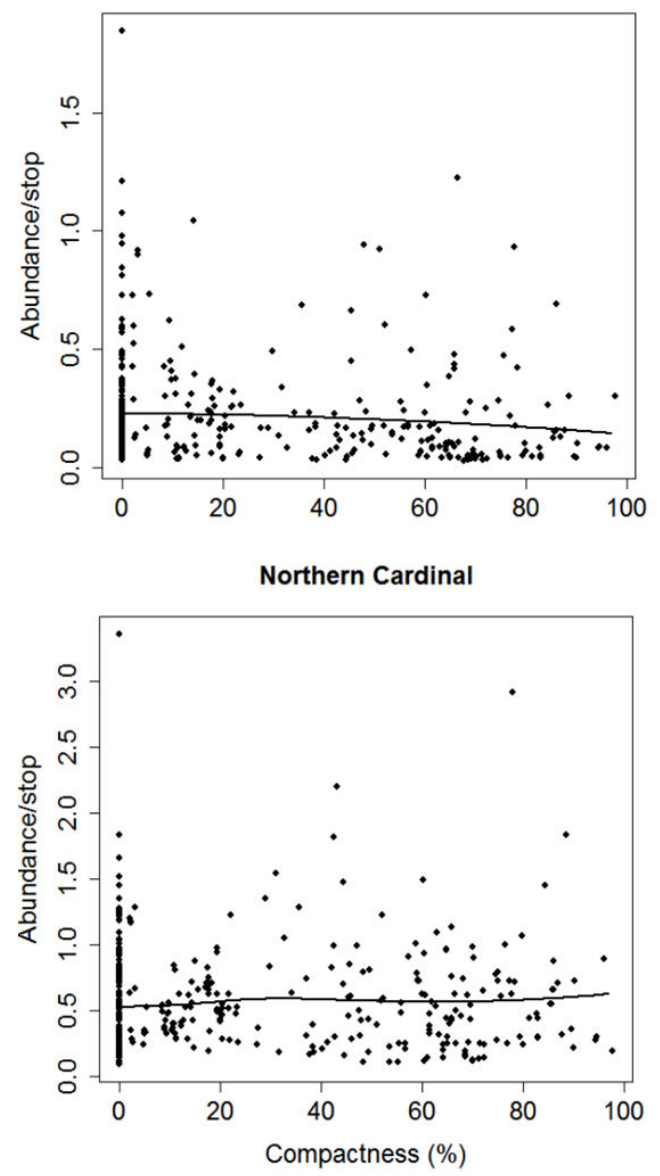

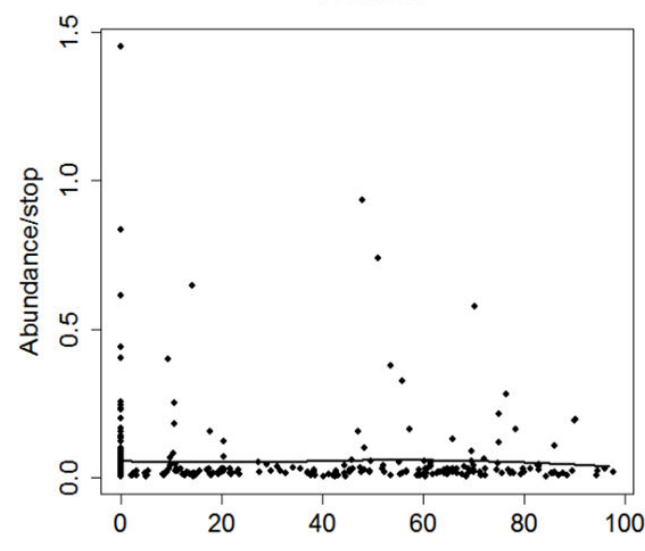

Wood Thrush

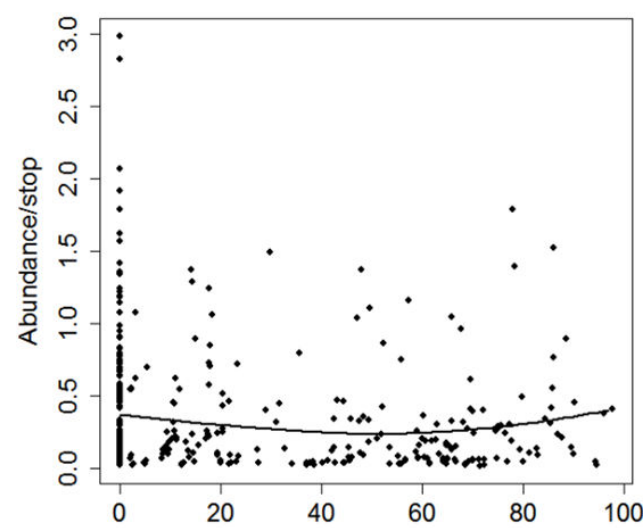

Gray Catbird

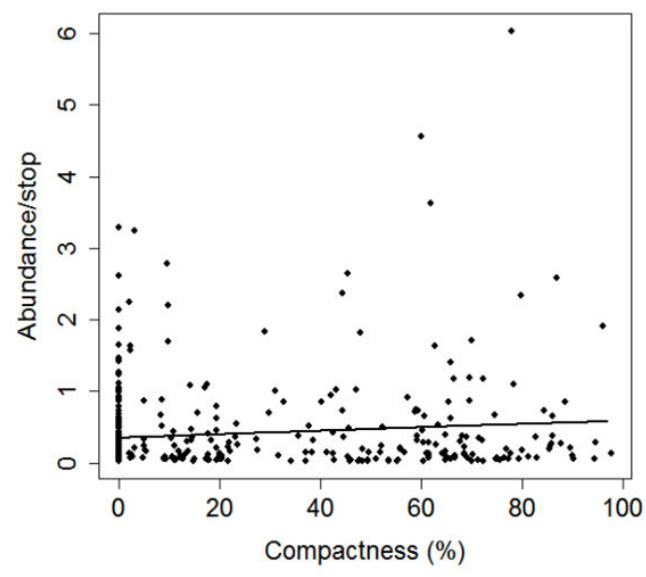


B. PeerJ

American Redstart

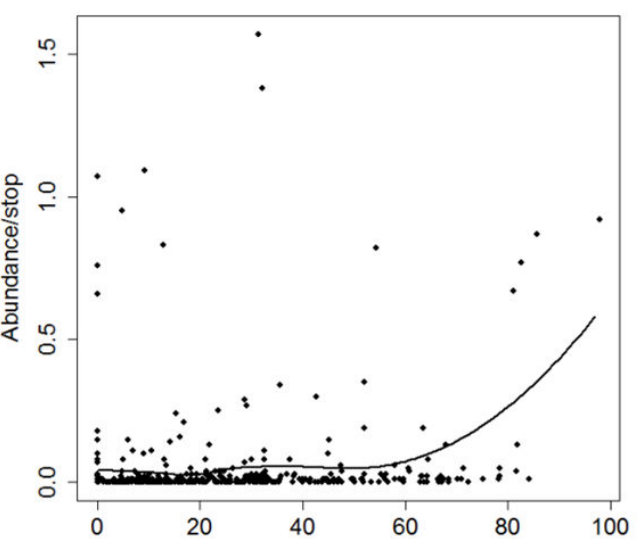

Red-eyed Vireo

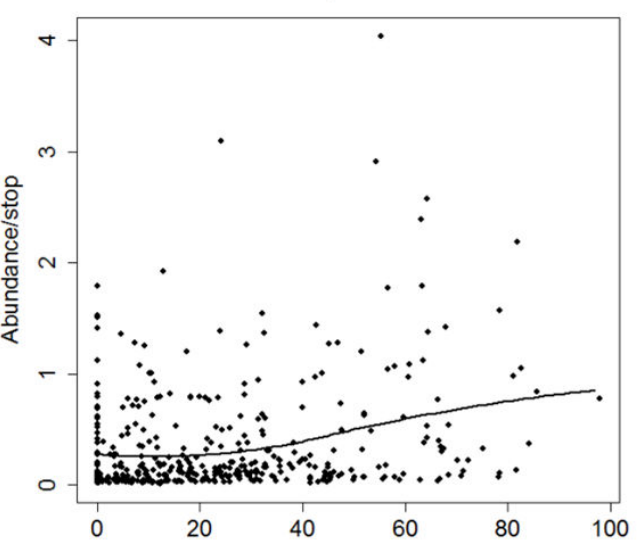

Eastern Phoebe

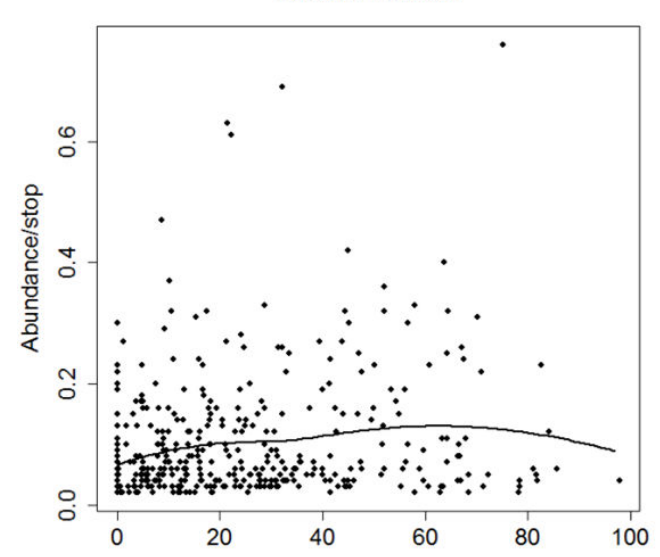

Indigo Bunting

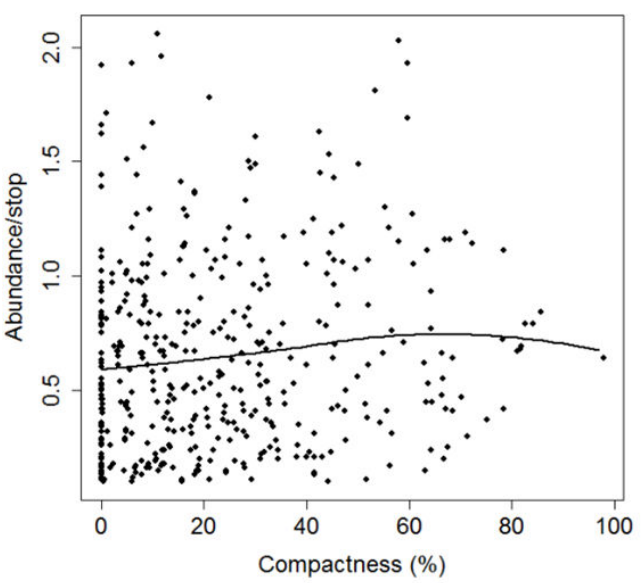

Manuscript to be reviewed
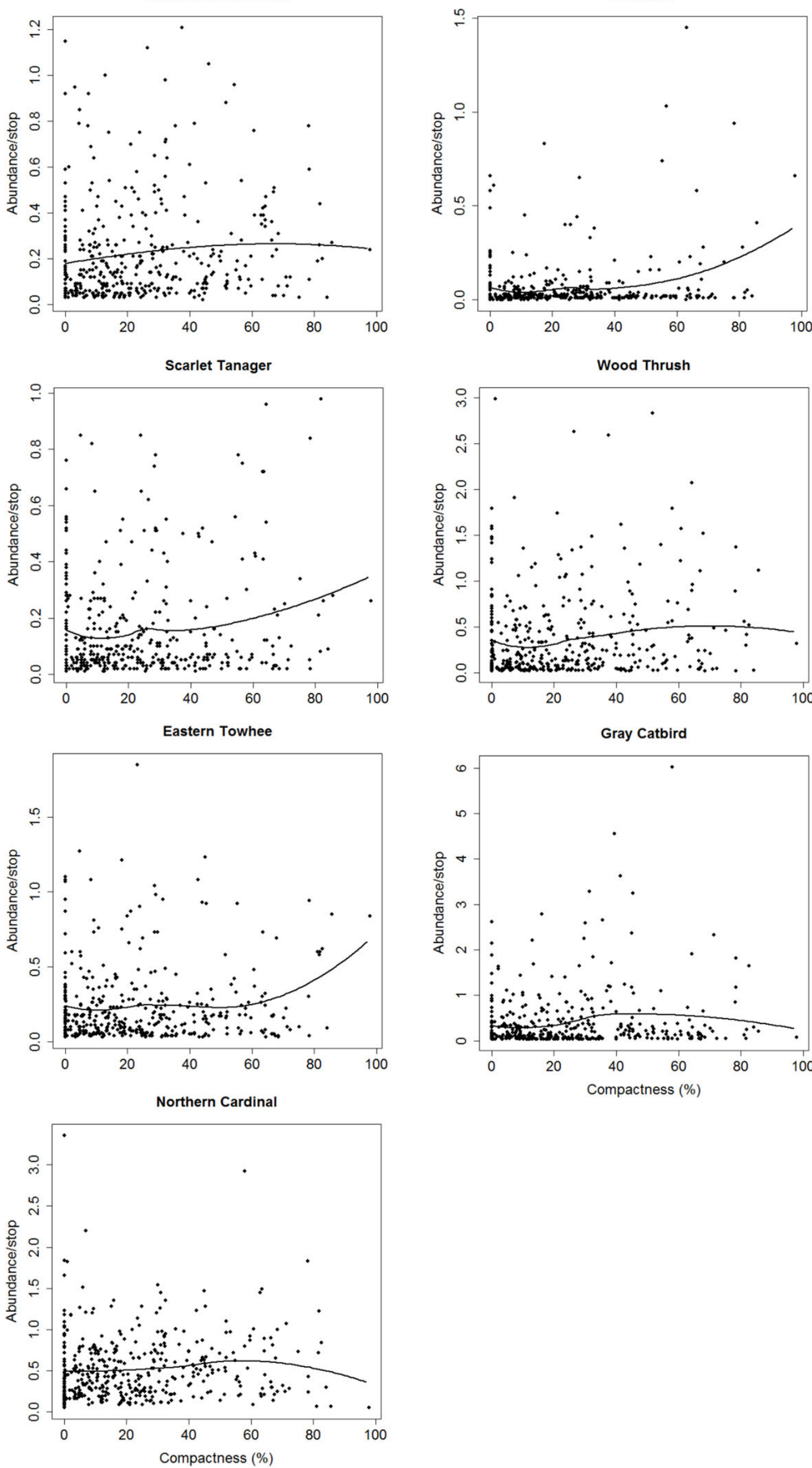

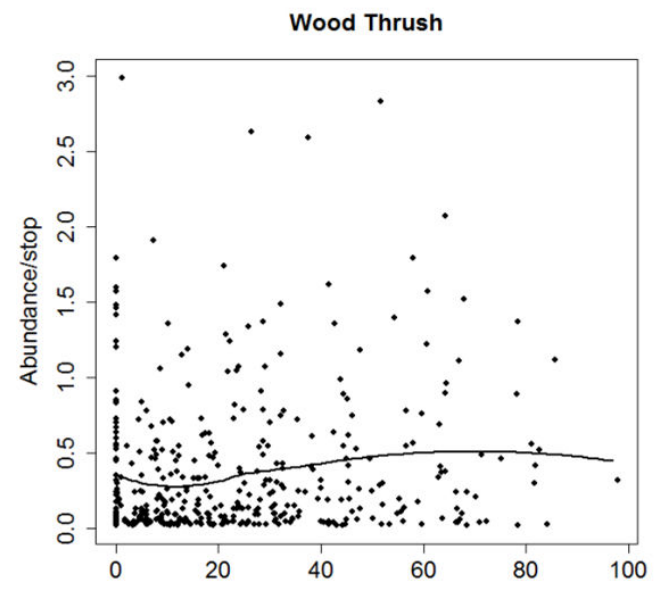

Gray Catbird

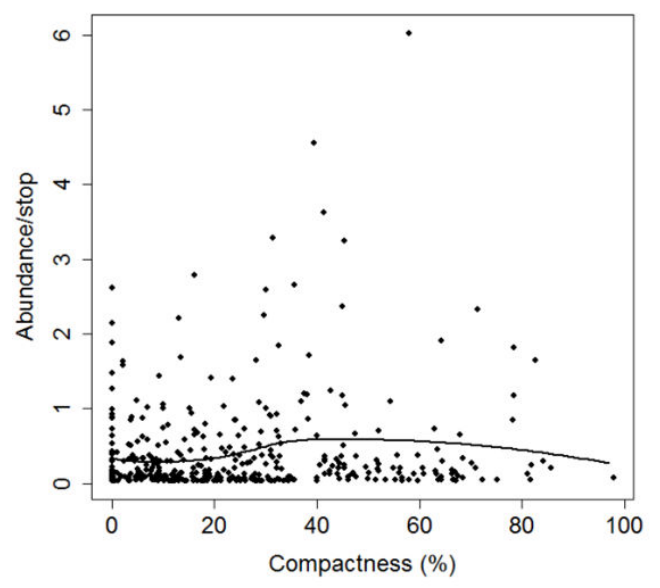




\section{Figure 4 (on next page)}

Change points of significant $(p<0.05)$ and reliable (purity $\geq 0.90$ and reliability $\geq 0.90$ ) indicator bird species of compactness of exurban development for (A) 400-m and (B) 1$\mathrm{km}$ radius buffer around selected BBS stops.

Solid circles represent negative response to compactness (with corresponding species on the left axes) and open circles correspond to a positive response (with corresponding species on the right axes). Circles are sized based on z scores and lines represent the 5 and $95 \%$ percentiles among bootstrap replicates. Short lines indicate nonlinear response, whereas long lines represent linear or more gradual response. Taxa IDs correspond to American Redstart (AMRE), Eastern Wood-Pewee (EAWP), Ovenbird (OVEN), Red-eyed Vireo (REVI), Scarlet Tanager (SCTA), Wood Thrush (WOTH), Eastern Phoebe (EAPH), Eastern Towhee (EATO), Gray Catbird (GRCA), Indigo Bunting (INBU), and Northern Cardinal (NOCA). Underlined codes denote forest-edge species. 


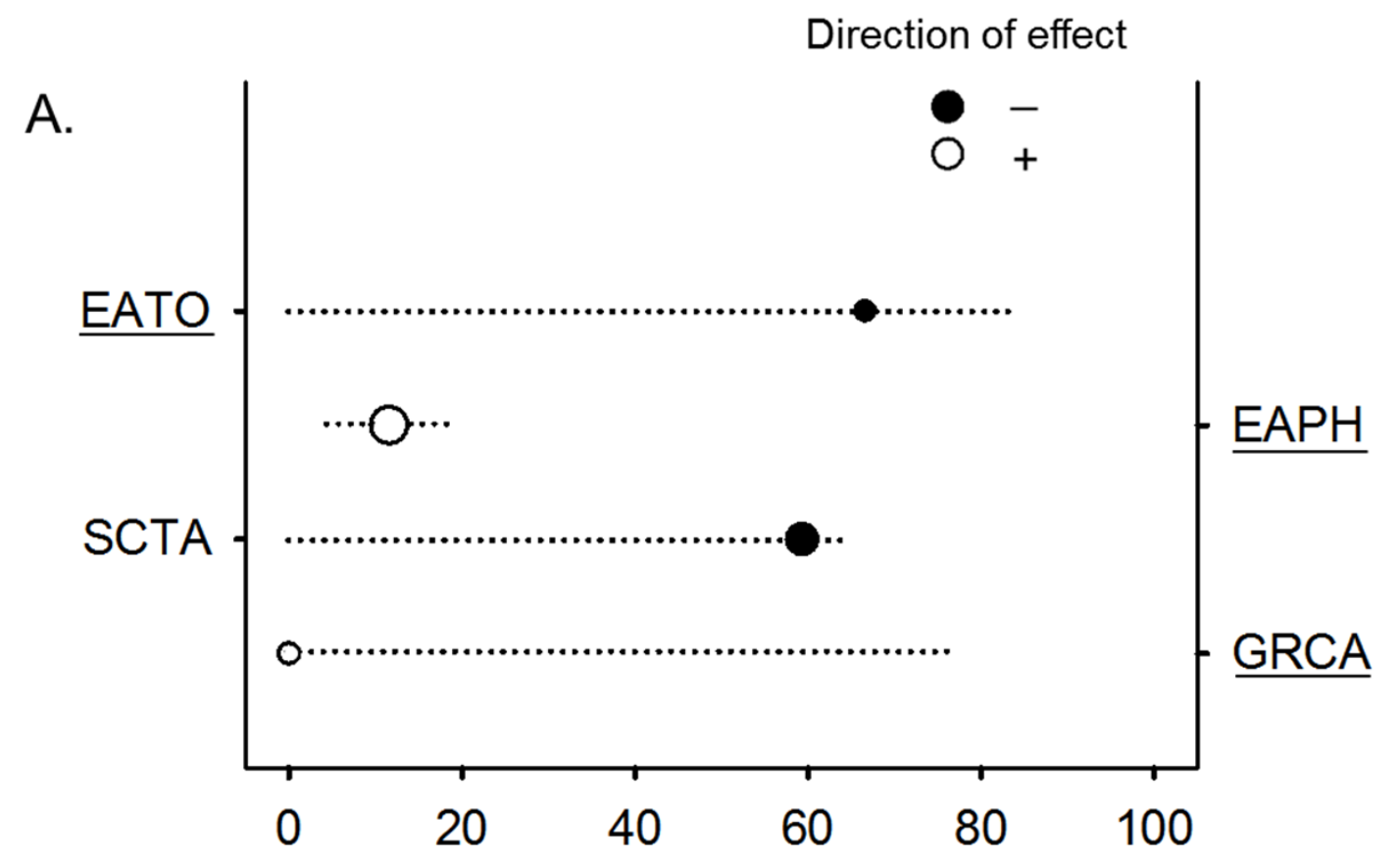

B.

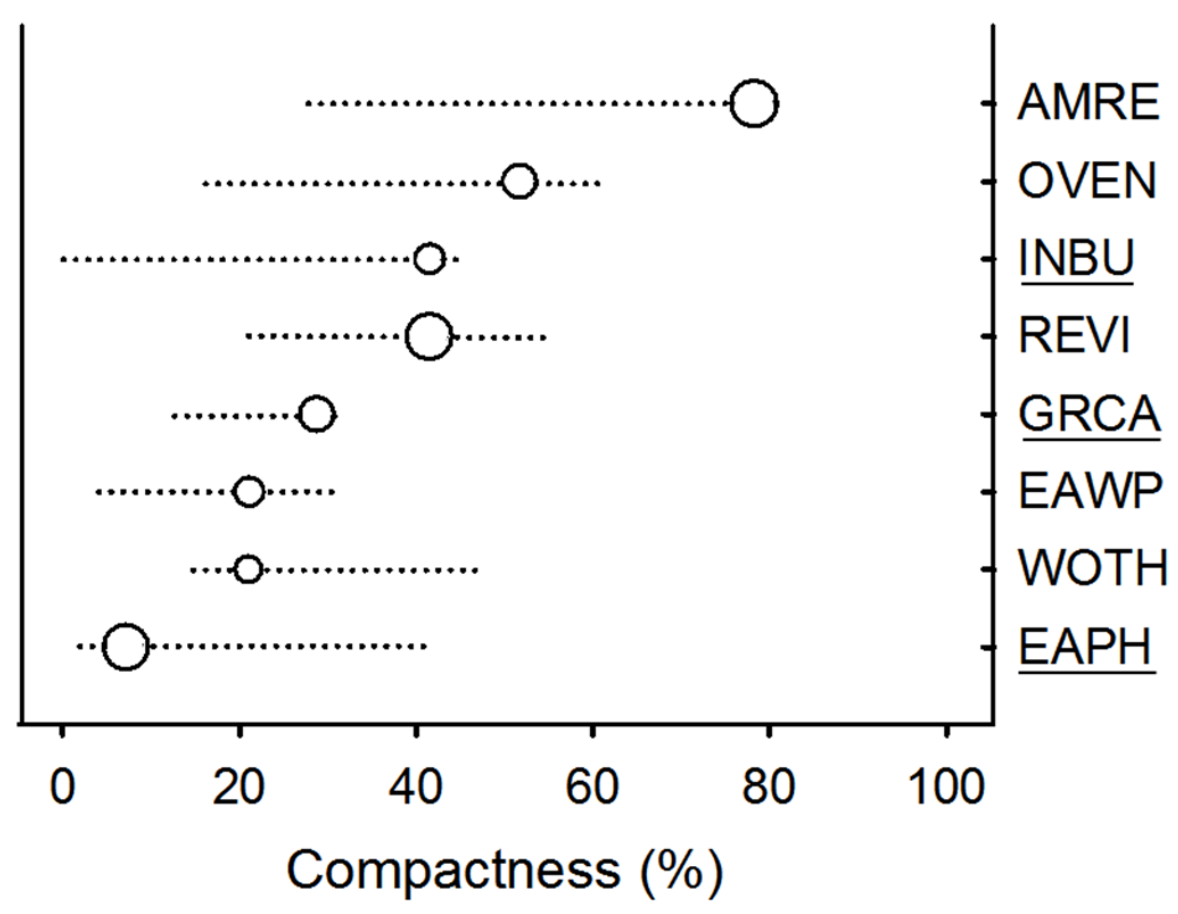


Table $\mathbf{1}$ (on next page)

Landscape composition and compactness of exurban development (mean \pm s.d.) at 400-m and 1-km radius buffer around selected Breeding Bird Survey stops from 1986 to 2009. 
1 Table 1: Landscape composition and compactness of exurban development (mean \pm s.d.) at 400-

$2 \mathrm{~m}$ and 1-km radius buffer around selected Breeding Bird Survey stops from 1986 to 2009

3

\begin{tabular}{lrrrr}
\hline Variables & \multicolumn{1}{c}{1986} & \multicolumn{1}{c}{1993} & \multicolumn{1}{c}{2000} & \multicolumn{1}{c}{2009} \\
\hline All survey stops & & & & \\
400- $m$ radius buffer $(n=97)$ & & & & \\
Forest (\%) & $34.5 \pm 32.3$ & $33.6 \pm 32.0$ & $31.4 \pm 31.0$ & $24.9 \pm 27.2$ \\
Exurban development (\%) & $11.4 \pm 6.5$ & $12.1 \pm 6.6$ & $13.4 \pm 6.9$ & $17.6 \pm 9.4$ \\
Compactness (\%) & $17.6 \pm 26.3$ & $18.1 \pm 25.8$ & $25.1 \pm 28.8$ & $38.9 \pm 34.3$ \\
l- $k m$ radius buffer $(n=105)$ & & & & \\
Forest (\%) & $41.2 \pm 30.9$ & $40.1 \pm 30.5$ & $38.5 \pm 30.3$ & $32.4 \pm 28.6$ \\
Exurban development (\%) & $10.0 \pm 4.6$ & $10.9 \pm 4.8$ & $12.1 \pm 5.3$ & $16.1 \pm 7.4$ \\
Compactness (\%) & $11.2 \pm 12.6$ & $13.6 \pm 13.3$ & $23.2 \pm 18.0$ & $43.9 \pm 23.5$
\end{tabular}

Survey stops in protected area $(n=26)$

400-m radius buffer

$\begin{array}{lrrrr}\text { Forest (\%) } & 100.0 \pm 0.0 & 100.0 \pm 0.0 & 99.9 \pm 0.4 & 99.9 \pm 0.4\end{array}$

$\begin{array}{lllll}\text { Exurban development (\%) } & 0.0 \pm 0.0 & 0.0 \pm 0.0 & 0.0 \pm 0.0 & 0.1 \pm 0.3\end{array}$

$1-k m$ radius buffer
Forest (\%)
$98.7 \pm 3.5$
$98.7 \pm 3.7$
$98.6 \pm 3.8$
$98.1 \pm 4.5$
Exurban development (\%)
$0.3 \pm 1.0$
$0.3 \pm 1.0$
$0.4 \pm 1.1$
$0.7 \pm 1.8$ 


\section{Table 2 (on next page)}

Threshold Indicator Taxa ANalysis (TITAN) results at the 400-m and 1-km radius buffer.

Significant $(p<0.05)$ and reliable (purity $\geq 0.90$ and reliability $\geq 0.90)$ indicator species are shown in bold. 
1 Table 2: Threshold Indicator Taxa ANalysis (TITAN) results at the 400-m and 1-km radius

2 buffer. Significant $(p<0.05)$ and reliable (purity $\geq 0.90$ and reliability $\geq 0.90)$ species are shown

3 in bold

4

\begin{tabular}{|c|c|c|c|c|c|c|c|c|}
\hline \multirow[b]{2}{*}{ Species } & \multirow[b]{2}{*}{$\begin{array}{c}\text { Direction of } \\
\text { effect }\end{array}$} & \multirow[b]{2}{*}{$\mathrm{z}$} & \multicolumn{3}{|c|}{ Change point } & \multirow[b]{2}{*}{ Purity } & \multirow[b]{2}{*}{ Reliability } & \multirow[b]{2}{*}{$p$} \\
\hline & & & Obs. & $5 \%$ & $95 \%$ & & & \\
\hline
\end{tabular}

Forest birds

$\begin{array}{lrrrrrrrr}\text { AMRE } & - & 0.94 & 0.00 & 0.00 & 84.92 & 0.54 & 0.31 & 0.180 \\ \text { EAWP } & - & 1.28 & 89.19 & 0.00 & 89.58 & 0.54 & 0.47 & 0.116 \\ \text { OVEN } & - & 1.84 & 0.00 & 0.00 & 87.40 & 0.59 & 0.38 & 0.052 \\ \text { REVI } & - & 1.52 & 0.00 & 0.00 & 86.16 & 0.56 & 0.40 & 0.072 \\ \text { SCTA } & - & 4.85 & 59.33 & 0.00 & 64.09 & 1.00 & 0.99 & 0.004 \\ \text { WOTH } & - & 3.00 & 18.81 & 0.00 & 77.75 & 0.81 & 0.80 & 0.012 \\ \text { Forest-edge species } & & & & & & & & \\ \text { EAPH } & + & 5.81 & 11.57 & 4.40 & 19.30 & 0.98 & 0.98 & 0.004 \\ \text { EATO } & - & 3.06 & 66.60 & 0.00 & 82.98 & 0.93 & 0.91 & 0.004 \\ \text { GRCA } & + & 3.26 & 0.00 & 0.00 & 78.92 & 0.96 & 0.94 & 0.008 \\ \text { INBU } & + & 3.41 & 9.05 & 0.00 & 85.84 & 0.90 & 0.89 & 0.008 \\ \text { NOCA } & + & 1.95 & 74.91 & 0.00 & 89.19 & 0.80 & 0.71 & 0.056\end{array}$

1-km radius buffer

Forest birds

\begin{tabular}{llrrrrrrr} 
AMRE & + & 7.03 & 78.26 & 27.58 & 80.66 & 1.00 & 1.00 & 0.004 \\
EAWP & + & 4.45 & 21.11 & 4.00 & 31.27 & 0.99 & 0.98 & 0.004 \\
OVEN & + & 5.16 & 51.70 & 16.07 & 61.89 & 0.99 & 0.99 & 0.004 \\
REVI & + & 6.99 & 41.47 & 20.98 & 55.16 & 1.00 & 1.00 & 0.004 \\
SCTA & + & 3.92 & 53.86 & 0.00 & 60.16 & 0.89 & 0.89 & 0.008 \\
WOTH & + & 4.06 & 20.98 & 14.98 & 47.12 & 0.97 & 0.96 & 0.004 \\
Forest-edge species & & & & & & & & \\
EAPH & + & 6.86 & 7.15 & 1.85 & 41.76 & 1.00 & 1.00 & 0.004 \\
EATO & + & 2.73 & 78.26 & 0.00 & 81.38 & 0.86 & 0.84 & 0.016 \\
GRCA & + & 5.25 & 28.74 & 12.46 & 31.33 & 1.00 & 0.99 & 0.004 \\
INBU & + & 4.48 & 41.54 & 0.00 & 45.00 & 0.99 & 0.98 & 0.004 \\
NOCA & + & 4.13 & 28.54 & 0.00 & 81.74 & 0.82 & 0.82 & 0.004 \\
\hline
\end{tabular}




\section{Table 3 (on next page)}

Summary of generalized additive models (GAM) for forest and forest-edge bird species at the $1-\mathrm{km}$ radius buffer.

Only species in which the model was a good fit were included. Smoother is represented by $s$ and year was included as a factor in the model therefore a smooth term did not apply. $\triangle A I C$; was used to rank models and only full and best-fitted model are shown. Significant values ( $p$ $<0.01$ ) are shown in bold 
2 Table 3: Summary of generalized additive models (GAM) for forest and forest-edge bird species at the 1-km radius buffer. Only

3 species in which the model was a good fit were included. Smoother is represented by $s$ and year was included as a factor in the model

4 therefore a smooth term did not apply. $\Delta \mathrm{AIC}_{i}$ was used to rank models and only full and best-fitted model are shown. Significant

5 values $(p<0.01)$ are shown in bold

\begin{tabular}{|c|c|c|c|c|c|c|c|c|c|c|c|}
\hline & & & Forest & $\begin{array}{c}\text { Exurban } \\
\text { development }\end{array}$ & Compactness & $\begin{array}{c}\text { Forest } \\
\text { patches }> \\
0.45 \text { ha }\end{array}$ & $\begin{array}{l}\text { Forest } \\
\text { edge }\end{array}$ & Year & $\begin{array}{c}\text { Deviance } \\
\text { explained } \\
(\%)\end{array}$ & $\mathrm{GCV}$ & $\Delta \mathrm{AIC}_{i}$ \\
\hline \multicolumn{12}{|c|}{ Forest birds } \\
\hline \multirow{2}{*}{ EAWP } & & $p$ & $<0.001$ & 0.049 & 0.001 & 0.745 & 0.356 & 0.016 & & & \\
\hline & best-fitted & $\mathrm{S}$ & 7 & 5 & 2 & & & 3 & 30.2 & 0.649 & 0 \\
\hline \multirow[t]{4}{*}{ REVI } & full & $\mathrm{s}$ & 1 & 1 & 1 & 7 & 2 & 3 & 66.5 & 0.554 & 0.120 \\
\hline & & $p$ & $<0.001$ & 0.004 & $<0.001$ & 0.007 & 0.320 & 0.006 & & & \\
\hline & best-fitted & $\mathrm{s}$ & 1 & 1 & 1 & 7 & & 3 & 65.2 & 0.554 & 0 \\
\hline & & $p$ & $<0.001$ & $<0.001$ & $<0.001$ & 0.008 & & 0.012 & & & \\
\hline SCTA & & $p$ & $<0.001$ & 0.003 & & 0.003 & 0.081 & 0.810 & & & \\
\hline \multirow[t]{3}{*}{ WOTH } & full & $\mathrm{s}$ & 1 & 5 & 2 & 7 & 6 & 3 & 42.0 & 0.999 & 2.955 \\
\hline & & $p$ & $<0.001$ & 0.091 & 0.006 & 0.013 & 0.094 & 0.585 & & & \\
\hline & best-fitted & $\mathrm{s}$ & 4 & 5 & 3 & 7 & & & 40.8 & 0.990 & 0 \\
\hline
\end{tabular}




$$
\begin{array}{lllll}
p & <\mathbf{0 . 0 0 1} & 0.039 & \mathbf{0 . 0 0 5} & 0.012
\end{array}
$$

Forest-edge species

EAPH full \&

best-fitted

s

2

1

3

0.003

0.022

0.120

$<0.001$

EATO full \&
best-fitted

2

1

2

9

$\begin{array}{lll}0.259 & \mathbf{0 . 0 0 1} & 0.875\end{array}$

GRCA full

$$
p \quad<\mathbf{0 . 0 0 1}
$$

0.199

8

$\begin{array}{lrrrr}\text { full } & \mathrm{s} & 2 & 2 & 5 \\ \text { best-fitted } & \mathrm{s} & 0.018 & 0.096 & 0.047 \\ & p & 0.040 & 0.102 & 5 \\ & p & & 3 & 0.040\end{array}$

$\begin{array}{rrrrrr}1 & 8 & 3 & 16.7 & 1.520 & 0.435 \\ 0.131 & 0.026 & 0.805 & & & \\ & 8 & 3 & 16.6 & 1.518 & 0 \\ & \mathbf{0 . 0 0 7} & 0.715 & & & \end{array}$

INBU full

$\begin{array}{llrr}\text { full } & \mathrm{s} & 8 & 7 \\ \text { best-fitted } & p & <\mathbf{0 . 0 0 1} & \mathbf{0 . 0 0 1} \\ & \mathrm{s} & 7 & 7 \\ & p & <\mathbf{0 . 0 0 1} & <\mathbf{0 . 0 0 1}\end{array}$

1
0.233

$\begin{array}{rrrrrr}5 & 1 & 3 & 29.5 & 0.415 & 3.484 \\ \mathbf{0 . 0 0 6} & 0.234 & 0.634 & & & \\ \mathbf{5} & & & 28.2 & 0.411 & 0 \\ \mathbf{0 . 0 0 6} & & & & & \end{array}$

\begin{tabular}{lllrr} 
NOCA & full & $\mathrm{s}$ & 1 & 5 \\
& & $p$ & 0.306 & 0.264 \\
& best-fitted & $\mathrm{s}$ & & 5 \\
& & & $\mathbf{0 . 0 0 6}$ \\
\hline
\end{tabular}

\begin{tabular}{rrrrrrr}
1 & 4 & 1 & 3 & 11.6 & 0.462 & 4.823 \\
0.151 & 0.020 & 0.166 & 0.584 & & & \\
& 4 & & & 10.0 & 0.079 & 0 \\
& $\mathbf{0 . 0 0 9}$ & & & & & \\
\hline
\end{tabular}

6 